Adji, T.N., Cahyadi, A., 2016, Pentingnya Monitoring Parameter-Parameter Hidrograf Dalam Pengelolaan Airtanah di Daerah Karst, Seminar Nasional Ekohidrolika APCE-UNESCO, Jogjakarta, 12-14 Oktober 2016

\title{
Pentingnya Monitoring Parameter-Parameter Hidrograf Dalam Pengelolaan Airtanah di Daerah Karst
}

\author{
Oleh: \\ Tjahyo Nugroho Adji dan Ahmad Cahyadi \\ (Karst Research Group, Fakultas Geografi, UGM)
}

\section{A. PENDAHULUAN}

Persediaan airtanah dari akuifer karst dari waktu ke waktu dianggap semakin berharga dan semakin penting untuk penyediaan air minum (Adji dan Haryono-1999; Adji et al. 1999) Bahkan, di banyak tempat di seluruh penjuru dunia, airtanah karst menjadi satu-satunya sumber daya air minum yang tersedia. Faktanya, sekitar seperempat dari kebutuhan total air minum pada populasi global dunia dipasok oleh air karst (Goldscheider, 2002).

Akuifer karst memiliki sifat hidrogeologi yang kompleks dan unik jika dibandingkan dengan akuifer di kawasan lain, karena memiliki tiga sifat porositas (triple porosity) yaitu porositas berukuran kecil (diffuse), menengah (fissure), dan besar (conduit). Tiga sifat yang didasarkan pada besar kecilnya perkembangan porositas atau lorong ini tergantung dari tahapan dan intensifnya pelarutan batuan gamping oleh air (Domenico and Schwartz, 1990). Akibatnya, tingkat heterogenitas akuifer karst sangat tinggi dan bersifat anisotropis; serta pada karst yang telah berkembang akan memiliki konduktivitas hidraulik yang tinggi (White and Elizabeth, 2003; Ford and William, 2007). Karena kondisi inilah, maka daerah karst merupakan salah satu jenis akuifer terbaik di muka bumi dalam hal menyimpan air hujan yang jatuh di atasnya dan kemudian dialirkan untuk menyuplai sungai bawah tanah (SBT) atau mataair dengan sifat pengaliran tergantung dari tingkat perkembangan porositasnya (Adji, 2010).

Namun, sistem airtanah di akuifer secara umum diasumsikan terdiri dari berbagai komponen terpisah, yang sangat mempengaruhi infiltrasi dari permukaan ke bawah permukaan, yaitu air yang berasal atau tersimpan di zone epikarst dan zona vadose. Komponen-komponen ini sangat rentan terhadap kontaminasi akibat infiltrasi yang cepat yang kemudian tertransportasikan melalui porositas akuifer yang telah berkembang yang sering dikenal sebagai sistem jaringan saluran (Leibundgut, 1998). Komponen simpanan airtanah di akuifer karst yang paling penting adalah yang tersedia di zone epikarst. Epikarst ini secara lugas didefinisikan sebagai suatu bentuk simpanan air yang tersimpan dekat dengan permukaan batuan gamping, yang menyimpan dan selanjutnya menjadi komponen utama penyebaran air menuju sungai bawah tanah (SBT) atau mataair karst melalui tiga jenis lorong atau porositas yang berkembang di akuifer karst (Mangin 1975; Williams 1983), sebagaimana yang diilustrasikan pada Gambar 1. Di sisi lain, hampir semua kegiatan manusia di permukaan karst, misalnya pertanian, peternakan, permukiman atau pertambangan adalah penyebab bagi menyebarnya berbagai jenis kontaminasi dari zone epikarst menuju sungai bawah tanah (SBT) dan mataair karst. Dalam hal ini, Margat (1968) memperkenalkan istilah kerentanan airtanah karst terhadap kontaminasi (vulnerability of karst groundwater to contamination) untuk membedakan dengan istilah kerentanan secara umum. Berkaitan dengan teori kerentanan karst tersebut, maka penting untuk dipahami sejauh mana tingkat perkembangan lorong karst 
Adji, T.N., Cahyadi, A., 2016, Pentingnya Monitoring Parameter-Parameter Hidrograf Dalam Pengelolaan Airtanah di Daerah Karst, Seminar Nasional Ekohidrolika APCE-UNESCO, Jogjakarta, 12-14 Oktober 2016

yang ada di suatu kawasan karst, sehingga manajemen sumberdaya air suatu kawasan karst dapat direncanakan atas dasar tahapan perkembangan akuifer karstnya (Doerflinger and Zwahlen,1998)

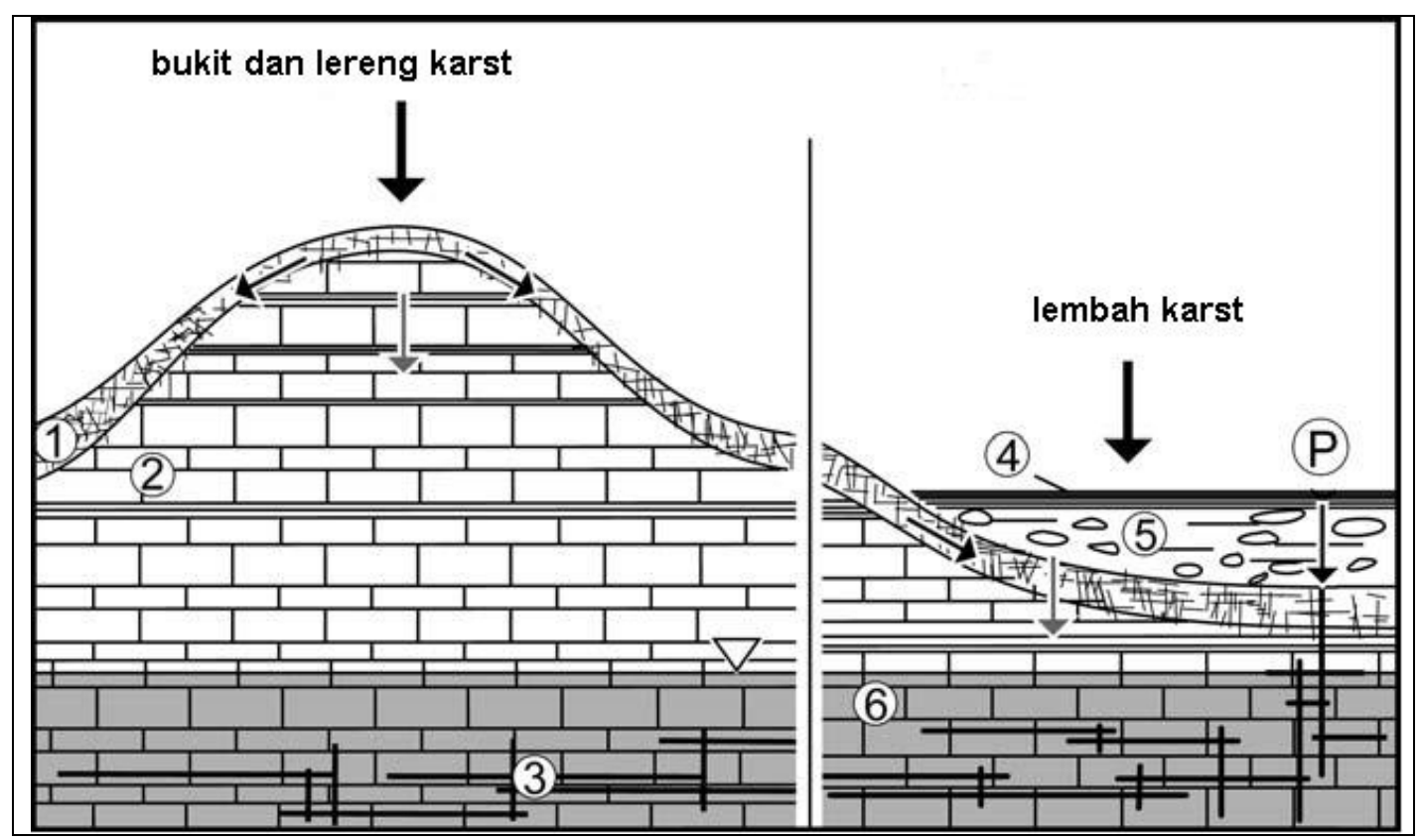

Gambar 1. Skema kemungkinan pergerakan air dari permukaan karst ke zona jenuh (1)epikarst; (2)batugamping kering; (3)proses pelebaran lorong; (4)tanah atas; (5)tanah bawah; (6) batu gamping jenuh air (Brosig, et al., 2008)

Selanjutnya, Adji (2016) menyampaikan bahwa secara kualitas dan kuantitas, kerusakan mataair yang disuplai oleh epikarst dapat dikenali dengan keruhnya mataair saat musim penghujan, naiknya fluktuasi tahunan, turunnya debit minimum, naiknya debit maksimum, dan turunnya prosentase aliran dasar. Paramater-parameter tersebut, selain merupakan parameter untuk menilai tingkat perkembangan karst, juga dapat digunakan untuk menilai jika terjadi perubahan yang sifatnya tidak alami atau (drastis), yang mengindikasikan terjadinya kerusakan media penyimpan airtanah karst karena gangguan aktivitas manusia.

Lebih jauh lagi, secara tradisional, para ahli telah sepakat dan meyakini bahwa analisis hidrograf (hubungan antara debit aliran dan waktu) pada mataair atau sungai bawah tanah (SBT) karst mampu memberikan pengetahuan yang lebih detail terkait sifat pelorongan internal akuifer, karakteristik, jenis aliran dan menggambarkan kondisi daerah imbuhan mataair atau sungai bawah tanah (Bonacci, 1993; Kresic dan Bonacci, 2010; Mohammadi and Shoja, 2013). Rashed (2012) juga mengusulkan metode lain dengan menggunakan beberapa parameter hidrograf aliran (rising and recession limb, time to peak, time to baseflow, and time event) untuk menentukan sejauh mana perkembangan karstifikasi pada suatu akuifer karst, sebagaimana parameter-parameter hidrograf lain yang juga digunakan oleh Malik danVotjkova (2012), terkait penentuan perkembangan aliran di akuifer karst.

Dalam mengelola sumberdaya airtanah di daerah karst, kebijakan yang diambil tentunya harus disesuaikan dengan sifat dan perkembangan akuifernya. Dengan kata lain, 
Adji, T.N., Cahyadi, A., 2016, Pentingnya Monitoring Parameter-Parameter Hidrograf Dalam Pengelolaan Airtanah di Daerah Karst, Seminar Nasional Ekohidrolika APCE-UNESCO, Jogjakarta, 12-14 Oktober 2016

sebelum pengelolaan dilakukan, harus dipilih metode yang disesuaikan dengan tahapan perkembangan karst yang selaras dengan perkembangan lorong, besar kecilnya cadangan air, dan sifat alirannya ketika menyuplai mataair atau sungai bawah tanah (SBT). Tulisan ini akan menyajikan sedikit teori tentang perkembangan karst, parameter-parameter hidrograf aliran, serta bagaimana menentukan tingkat perkembangan karst di suatu wilayah ditinjau dari parameter hidrograf yang diperoleh dari pemasangan instrumen pencatat hidrograf di mataair atau sungai bawah tanah karst. Selanjutnya parametyer-parameter tersebut merupakan datadata penting yang mutlak digunakan untuk manajemen sumberdaya airtanah karst.

\section{B. PERKEMBANGAN AKUIFER KARST}

Secara umum, perkembangan lorong atau porositas pada akuifer dikenal sebagai proses solusional (karstifikasi) karena secara kimia terjadi pelarutan (dissolution) batugamping oleh air yang kaya $\mathrm{CO}_{2}$ (Trudgil, 1985). Beberapa faktor pendorong dan pengontrol cepatlambatnya proses karstifikasi di antaranya adalah kemurnian, ketebalan, umur, dan kekompakan batugamping, sebaran rekahan primer, curah hujan, suhu, vegetasi penutup, dan kondisi ekspose batuan di ketinggian (Haryono dan Adji, 2004). Atas dasar banyaknya faktor yang berpengaruh inilah, maka tingkat perkembangan akuifer karst akan sangat bervariasi secara spasial (Zhu et al., 2013). Konsekuensinya, Malik (2007) menjelaskan bahwa sifat simpanan dan pelepasan airtanah karst juga sangat tergantung pada tahapan karstifikasi yang terjadi di akuifer.

Untuk mengklasifikasi tingkat perkembangan akuifer karst, berbagai metode penelitian telah dikembangkan, di antaranya: (1) analisis hidrogeokimia, yakni dengan memantau variasi kandungan unsur kimia terlarut di mataair atau sungai bawah tanah karst (Shuster and White, 1971; Raeisi and Karami, 1997; Lastennet and Mudry, 1997); (2) analisis sistem linear (Dreiss, 1989); (3) rasio heterogenitas; (4) analisis resesi hidrograf banjir; dan (5) kecepatan akuifer karst dalam melepaskan air (aquifer flashiness). Lebih khusus lagi, analisis hidrograf ini dikatakan oleh Quinlan (1989) dan Quinlan et al. (1991), mampu menjelaskan data aliran yang lebih representative yang mencerminkan tingkat perkembangan lorong di akuifer.

Perkembangan lorong karst dapat dikenali dari perkembangan sistem aliran pada akuifernya yaitu yang menurut White $(1988 ; 1993)$ adalah adanya perkembangan tipe aliran rembesan (diffuse) menuju ke tipe aliran saluran (conduit), yang ditegaskan pula oleh Domenico dan Schwarts (1990). Sementara itu, Gillieson (1996) menambahkan bahwa di antara dua tpe aliran tersebut terdapat tipe celah (fissure). Gambaran dari tipe aliran sesuaiperkembangan di akuifer karst disajikan pada Gambar 2. Adapun secara istilah, Bonacci (1990) menyebutkan bahwa tipe aliran diffuse adalah komponen aliran yang mengalir melalui retakan-retakan pada batuan gamping yang berukuran $10^{-3}-10 \mathrm{~mm}$, sedangkan tipe aliran fissure mengalir pada retakan berukuran $10-10^{2} \mathrm{~mm}$, dan tipe aliran conduit mengalir pada retakan yang berukuran $10^{2}-10^{4} \mathrm{~mm}$ atau lebih. Semakin besar dominasi tipe aliran pada lorong yang besar (conduit), maka semakin berkembang pula akuifer karstnya. Pada karst yang telah berkembang baik, aliran diffuse sudah menjadi satu sistem dengan aliran conduit (mixed) dan memasok aliran airnya ke lorong-lorong conduit. 
Adji, T.N., Cahyadi, A., 2016, Pentingnya Monitoring Parameter-Parameter Hidrograf Dalam Pengelolaan Airtanah di Daerah Karst, Seminar Nasional Ekohidrolika APCE-UNESCO, Jogjakarta, 12-14 Oktober 2016

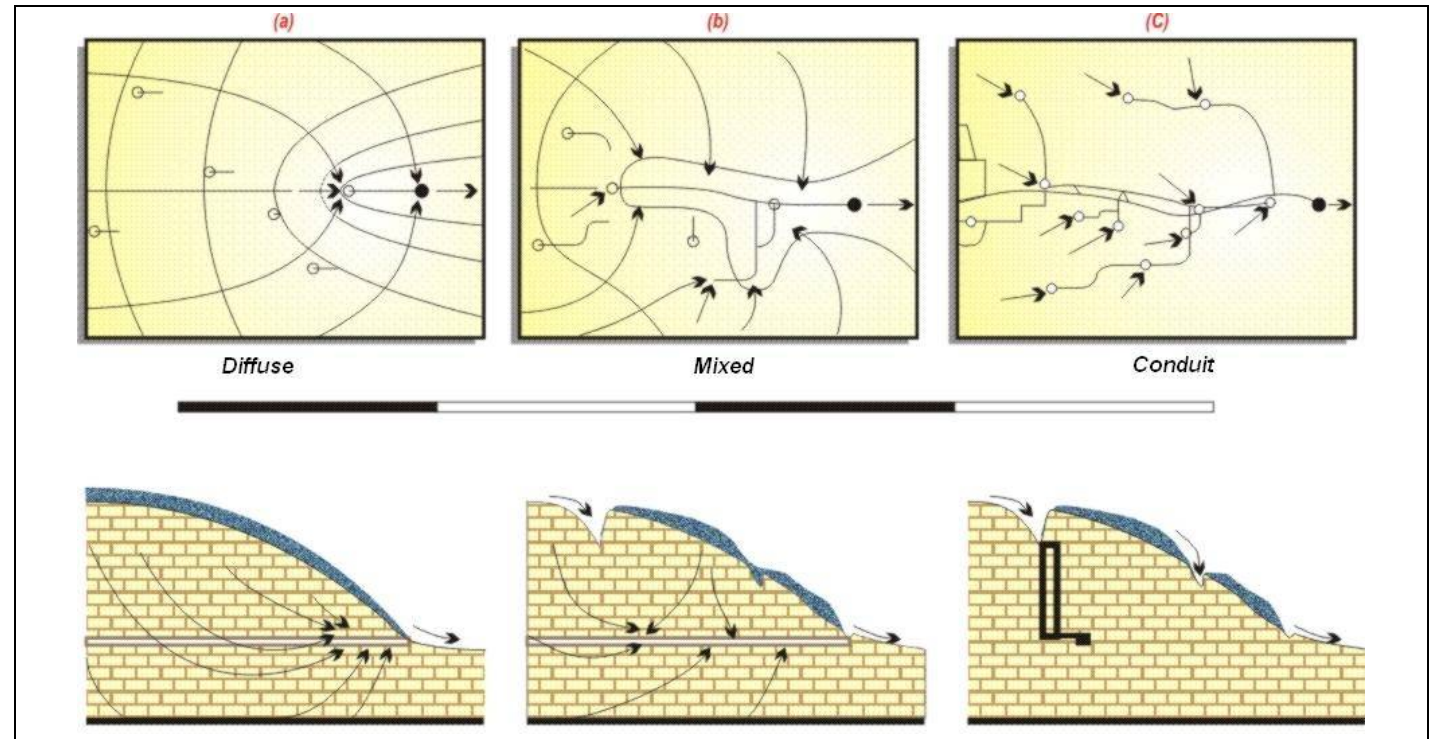

Gambar 2. Tipe aliran diffuse, campuran dan conduit di akuifer karst (Domenico and Schwartz, 1990)

Publikasi lain oleh Smart dan Hobbs (1986) mengungkapkan bahwa perkembangan akuifer karst mempunyai hubungan dengan perkembangan lorong, kondisi daerah tangkapan (DAS), serta besar kecilnya simpanan airtanah yang ada di akuifer (Tabel 1).

Tabel 1. Karakteristik Aliran Akuifer Karst (Smart dan Hobbs, 1986)

\begin{tabular}{|l|l|l|l|}
\hline $\begin{array}{c}\text { Tipe } \\
\text { aliran/lorong }\end{array}$ & \multicolumn{1}{|c|}{$\begin{array}{c}\text { Karakteristik dalam } \\
\text { mengimbuh mataair atau SBT }\end{array}$} & \multicolumn{1}{|c|}{$\begin{array}{c}\text { Kondisi Daerah } \\
\text { Tangkapan }\end{array}$} & \multicolumn{1}{c|}{ Simpanan airtanah } \\
\hline Diffuse & $\begin{array}{l}\text { Menyebar } \\
\text { Respon lambat terhadap hujan }\end{array}$ & $\begin{array}{l}\text { Fracture } \\
\text { Intergranuler }\end{array}$ & Besar dan sepanjang tahun \\
\hline Fissure & $\begin{array}{l}\text { Percelahan } \\
\text { Respon sedang terhadap hujan }\end{array}$ & $\begin{array}{l}\text { Fracture } \\
\text { Joint }\end{array}$ & Sedang dan perenial musiman \\
\hline Conduit & $\begin{array}{l}\text { Perpipaan (lorong) } \\
\text { Sangat cepat dan sensitif } \\
\text { terhadap hujan }\end{array}$ & $\begin{array}{l}\text { Banyak cekungan dengan } \\
\text { sinkhole dan ponor }\end{array}$ & $\begin{array}{l}\text { Rendah dan hanya tersedia pada } \\
\text { saat musim hujan }\end{array}$ \\
\hline
\end{tabular}

Dari Tabel 1 dapat dijelaskan bahwa tipe aliran yang dikontrol oleh besar kecilnya lorong yang telah berkembang berkorelasi pula dengan karakteristik airtanah ketika mengisi mataair atau sungai bawah tanah, kondisi permukaan daerah karst (DAS), serta banyak sedikitnya airtanah yang tersimpan di akuifer. Lebih lanjut, Smart dan Hobbs (1986) membuat model hidrograf aliran akuifer yang yang dapat digunakan untuk memprediksi tipe aliran yang dominan di akuifer, besar kecilnya simpanan, serta kondisi perkembangan daerah tangkapan untuk menginput air hujan ke dalam akuifer karst, sebagaimana yang disajikan pada Gambar 3.

Pendekatan hidrograf aliran untuk mengkarakterisasi sifat imbuhan, jumlah simpanan airtanah, dan jenis dominasi aliran di akuifer dikenal sebagai metode induktif atau inverse model (model terbalik), yaitu sifat penarikan kesimpulan yang mendekati Quasi-Experimental Research (Dane, 1990). Cara ini merupakan bagian dari Experimental Research yang merupakan tingkatan tertinggi dari suatu riset, karena banyaknya data yang diperoleh di lapangan dan bukan semata menggunakan metode Conceptual Research yang menggabungkan teori-teori yang ada untuk menarik suatu kesimpulan tertentu. Jika dianalogikan pada dunia 
Adji, T.N., Cahyadi, A., 2016, Pentingnya Monitoring Parameter-Parameter Hidrograf Dalam Pengelolaan Airtanah di Daerah Karst, Seminar Nasional Ekohidrolika APCE-UNESCO, Jogjakarta, 12-14 Oktober 2016

kesehatan, maka cara menarik kesimpulan ini seperti seorang dokter yang membaca data hasil tes urine dari laboraorium untuk menentukan kondisi sehat tidaknya ginjal seseorang, yang tentunya lebih akurat dibanding jika seorang dokter hanya mendeteksi atau mengamati kondisi fisik seorang pasien yang diduga mempunyai masalah pada ginjalnya.

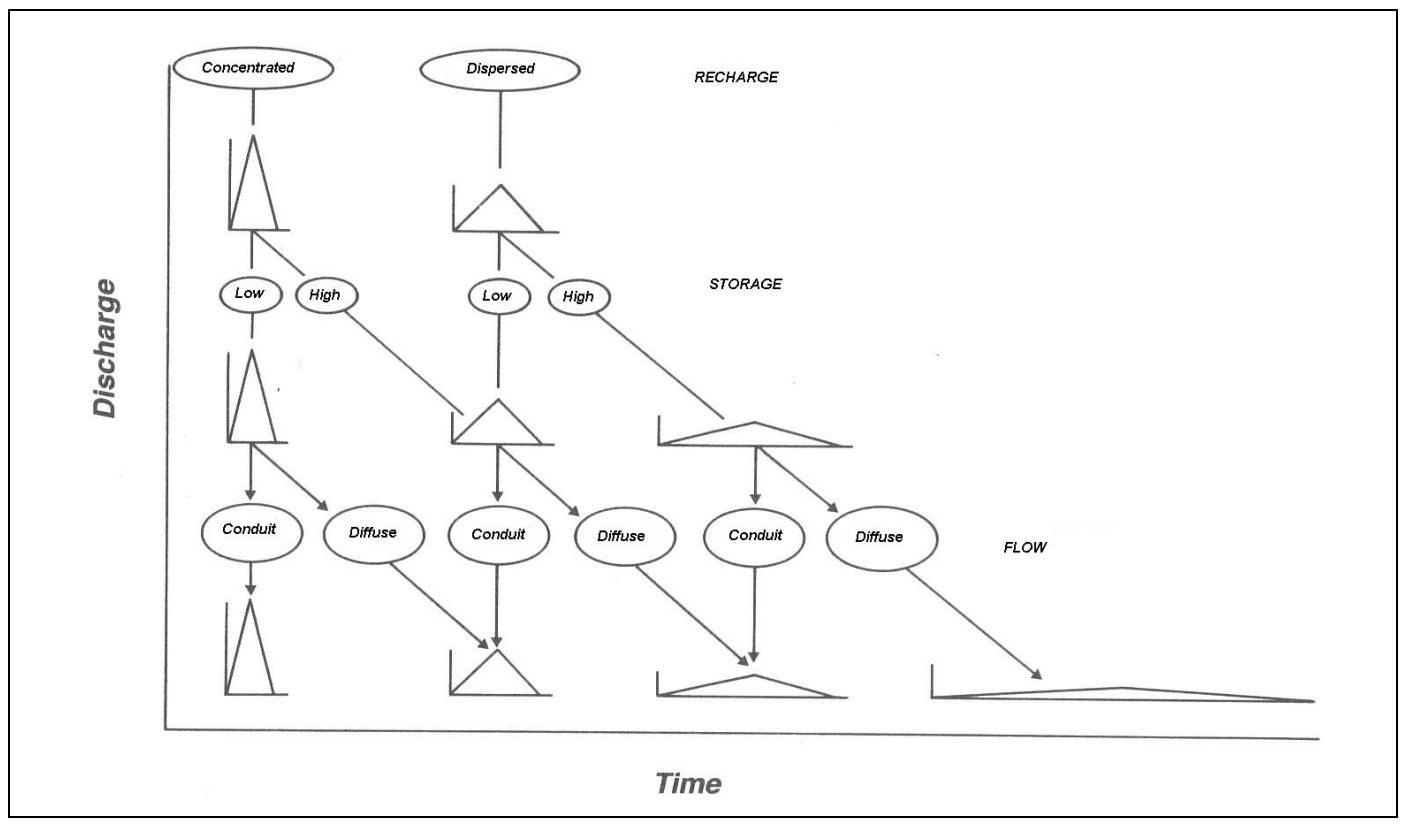

Gambar 3. Tiga Sub-Sistem Bertingkat yang Menghasilkan Perbedaan Hidrograf Aliran pada Mataair Karst (Smart dan Hobbs, 1986)

Pada akhirnya, dengan mengetahui hidrograf aliran suatu mataair atau sungai bawah tanah karst, akan didapatkan pula gambaran yang lebih jelas terkait jumlah simpanan airnya, sifat alirannya dalam mengimbuh mataair dan sungai bawah tanah, sifat banjirnya, cepat lambatnya air hujan masuk ke batuan gamping, serta jenis dan perkiraan ukuran lorong dan tingkatan perkembangan karstnya. Tentunya semua tadi akan menentukan manajemen atau pengelolaan sumberdaya airnya, karena manajemen yang baik akan mendasarkan pada rincian sifat-sifat akuifernya dan bukan dengan cara pengelolaan yang sifatnya global.

\section{PARAMETER HIDROGRAF AIRTANAH KARST}

\section{Hidrograf Banjir}

Hidrograf banjir (flood hydrograph) adalah hidrograf pada saat aliran dalam keadaan banjir, dengan bentuk hidrograf mirip lonceng yang miring ke kanan. Bentuk atau parameter hidrograf banjir memcerminkan kondisi daerah tangkapan, besar kecilnya simpanan, cara pelepasan aliran, dan hubungan respon mataair atau sungai bawah tanah karst terhadap hujan. Gambar 3. menunjukkan hidrograf banjir dan hujan penyebabnya. 
Adji, T.N., Cahyadi, A., 2016, Pentingnya Monitoring Parameter-Parameter Hidrograf Dalam Pengelolaan Airtanah di Daerah Karst, Seminar Nasional Ekohidrolika APCE-UNESCO, Jogjakarta, 12-14 Oktober 2016

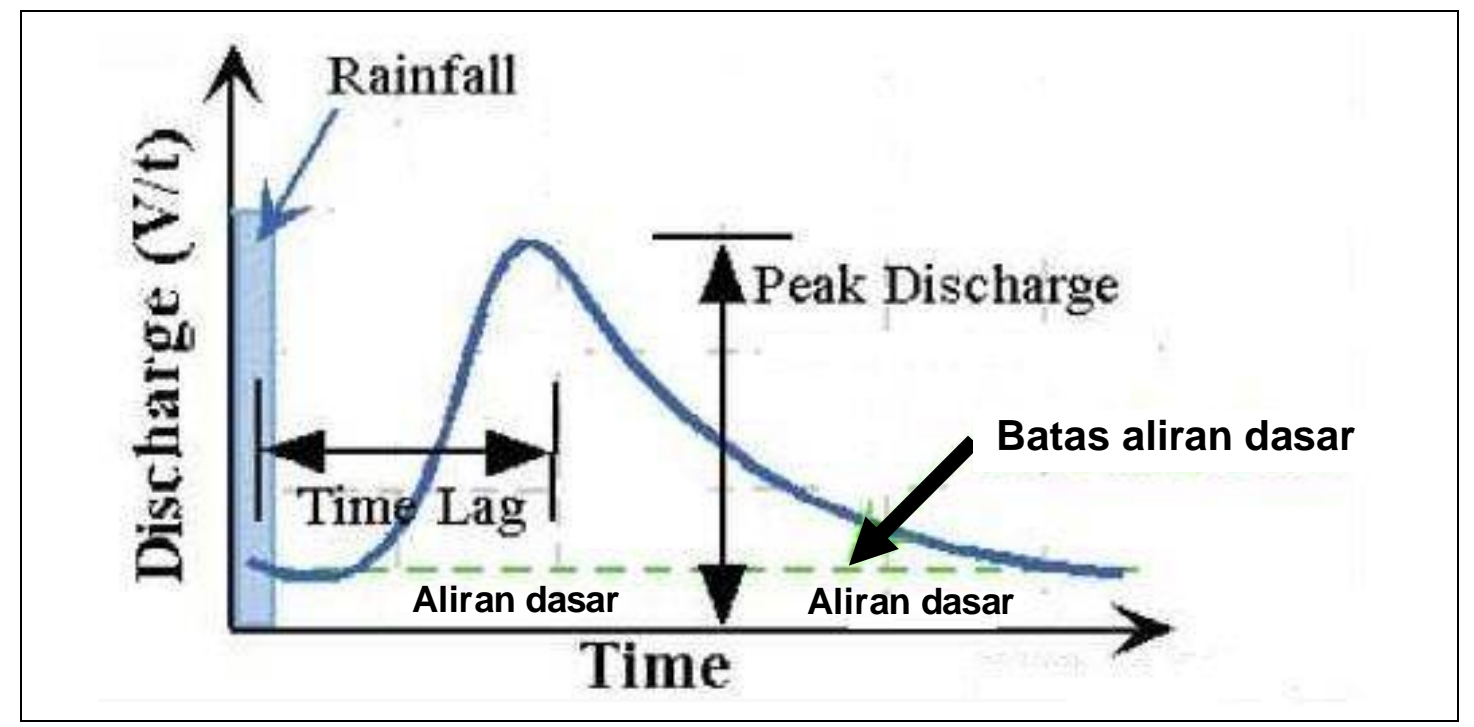

Gambar 3. Komponen hidrograf banjir

Pasangan data hujan dalam bentuk hietograf dan data aliran dalam bentuk hidrograf banjir sangat berguna untuk analisis hubungan hujan dengan tinggi aliran banjir, di antara parameter hidrologi yang bisa dihitung dari hidrograf banjir adalah (1)puncak banjir (Qp); (2) waktu konsentrasi (Time of concentration or time lag) $=\mathrm{T}_{c}$; (3) waktu mencapai puncak (time to peak $)=\mathrm{T}_{\mathrm{p}}$; (4) waktu dasar (time base) $=\mathrm{T}_{\mathrm{b}}$. Selain itu, dapat pula dikatakan bahwa karakteristik hidrograf merupakan cerminan dari kondisi daerah tangkapan permukaannya. Jika kondisi daerah tangkapan berubah, maka bentuk dan karakter hidrograf akan berubah pula (Gambar 4).

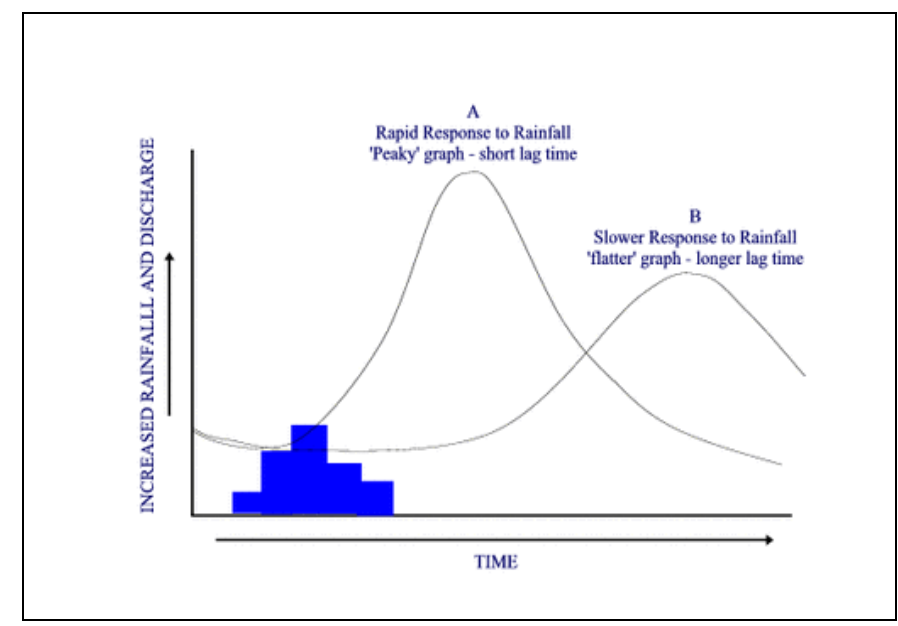

Gambar 4. Perubahan respon debit mataair karst terhadap hujan yang bisa mengindikasikan perubahan atau kerusakan daerah tangkapannya

Berikut ini contoh hidrograf banjir (Tabel 2) yang terekam di beberapa lokasi di Sungai Bawah Tanah Bribin, Gunungkidul, Provinsi DIY dan sedikit deskripsi kondisi akuifernya atas dasar kriteria Smart dan Hobbs (1986). 
Adji, T.N., Cahyadi, A., 2016, Pentingnya Monitoring Parameter-Parameter Hidrograf Dalam Pengelolaan Airtanah di Daerah Karst, Seminar Nasional Ekohidrolika APCE-UNESCO, Jogjakarta, 12-14 Oktober 2016

Tabel 1. Faktor-faktor Yang Berpengaruh Terhadap Hidrograf Aliran pada Gua-Gua di SBT Bribin

\begin{tabular}{|c|c|c|c|c|}
\hline Nama Gua & $\begin{array}{c}\text { Debit } \\
\text { andalan/PAD }\end{array}$ & Sifat Imbuhan & $\begin{array}{c}\text { Jumlah Simpanan di } \\
\text { Akuifer }\end{array}$ & Hidrograf \\
\hline \multicolumn{5}{|c|}{ Musim kemarau } \\
\hline Bribin & stabil & $\begin{array}{l}\text { Dispersed } \\
\text {-diffuse }\end{array}$ & Tinggi & \\
\hline Ngreneng & kecil & $\begin{array}{l}\text { Concentrated- } \\
\text { kering }\end{array}$ & Rendah & \\
\hline Gilap & kering & $\begin{array}{l}\text { Concentrated- } \\
\text { dispersed }\end{array}$ & Sedang-Rendah & \\
\hline \multicolumn{5}{|c|}{ Musim hujan } \\
\hline Bribin & cukup stabil & $\begin{array}{l}\text { Concentrated- } \\
\text { dispersed }\end{array}$ & Tinggi & \\
\hline Ngreneng & naik drastis & Concentrated & Rendah & \\
\hline Gilap & naik & $\begin{array}{l}\text { Dominan } \\
\text { concentrated }\end{array}$ & Sedang-Rendah & \\
\hline
\end{tabular}

Sumber: Adji (2010)

\section{Konstanta Resesi}

Di sungai permukaan, kita mengenal tiga jenis komponen aliran pengimbuh sungai (run-off) yaitu (i)aliran permukaan (channel flow); (ii)aliran antara (interflow); dan (iii)aliran dasar (baseflow). Sementara itu, dikenal pula padanannya pada sungai bawah tanah atau mata air karst yaitu: (i)conduit flow-setara aliran permukaan; (ii)fissure flow-setara aliran antara; dan (iii)diffuse flow-setara aliran dasar. Setelah hidrograf mencapai debit puncak dan kemudian turun, yaitu pada periode resesi, maka aliran conduit akan dilepaskan dan 
Adji, T.N., Cahyadi, A., 2016, Pentingnya Monitoring Parameter-Parameter Hidrograf Dalam Pengelolaan Airtanah di Daerah Karst, Seminar Nasional Ekohidrolika APCE-UNESCO, Jogjakarta, 12-14 Oktober 2016

dihabiskan pertama kali, yang disusul oleh aliran fissure, dan yang paling akhirnya adalah diffuse flow atau aliran dasar yang bisa bertahan sepanjang tahun tergantung nilai konstanta resesinya.

Konsep ini di antaranya disebutkan oleh Schulz (1976) yang menganggap sebuah akuifer sebagai suatu tanki penyimpan air yang setelah kejadian banjir akan berangsur-angsur melepaskan tiga komponen simpanan airnya seiring fungsi waktu, seperti yang disajikan pada Gambar 5.

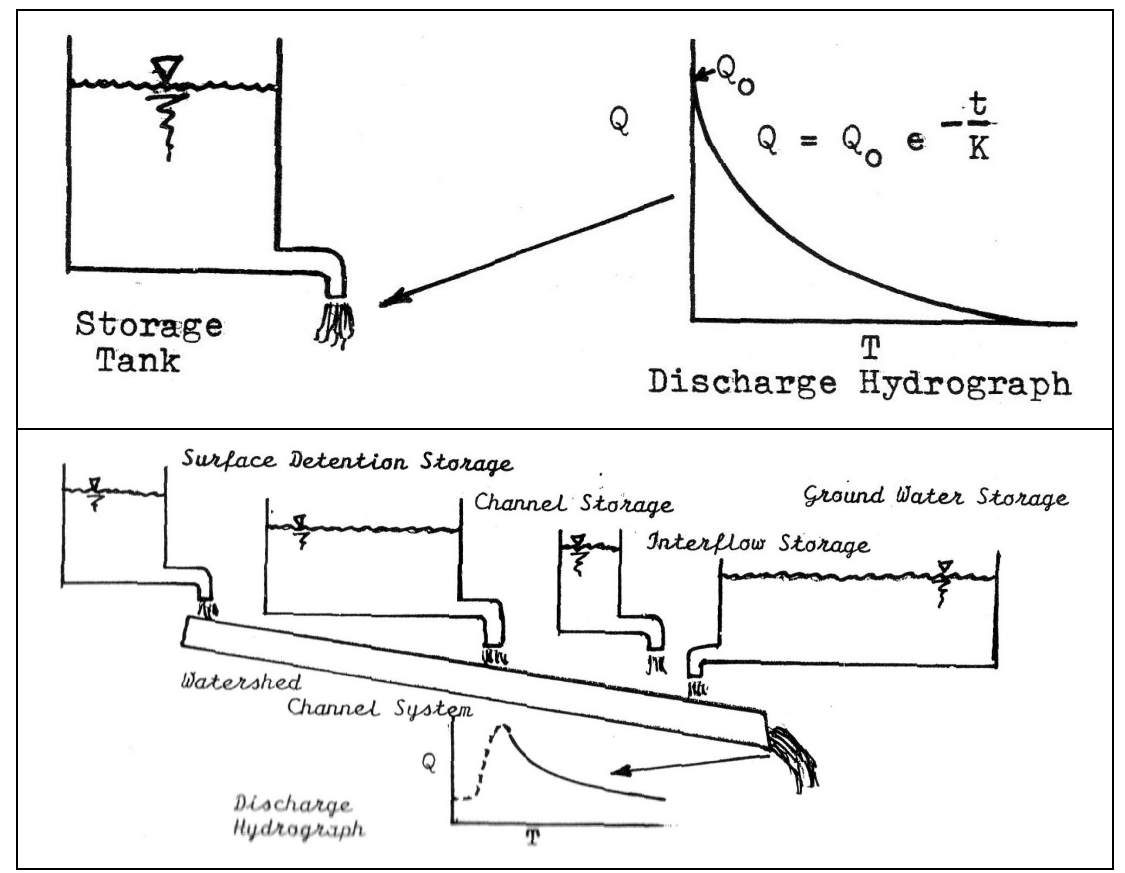

Gambar 5. Pelepasan simpanan air akuifer sebagai komponen aliran (Schulz, 1976)

Kurva resesi (Gambar 3-atas) merupakan bagian dari suatu hidrograf banjir (Gambar 3-bawah) pada sungai bawah tanah setelah tidak ada kejadian hujan, sehingga debit aliran turun atau akuifer melepaskannya komponen alirannya. Slope atau kemiringan dari kurva resesi semakin menjauhi puncak banjir akan semakin datar karena aliran conduit sudah dilepaskan sehingga aliran diffuse menjadi dominan. Periode kurva resesi ini terus berlangsung sampai terjadi kejadian banjir lagi. Jika mengacu pada Gambar 5, pada periode kurva resesi ini terjadi tiga kali pelepasan oleh masing-masing komponen aliran yaitu diffuse, fissure, dan conduit, yang jika kemudian kita namakan segmen resesi tentunya mempunyai slope yang berbeda-beda pula (Gambar 6). 
Adji, T.N., Cahyadi, A., 2016, Pentingnya Monitoring Parameter-Parameter Hidrograf Dalam Pengelolaan Airtanah di Daerah Karst, Seminar Nasional Ekohidrolika APCE-UNESCO, Jogjakarta, 12-14 Oktober 2016

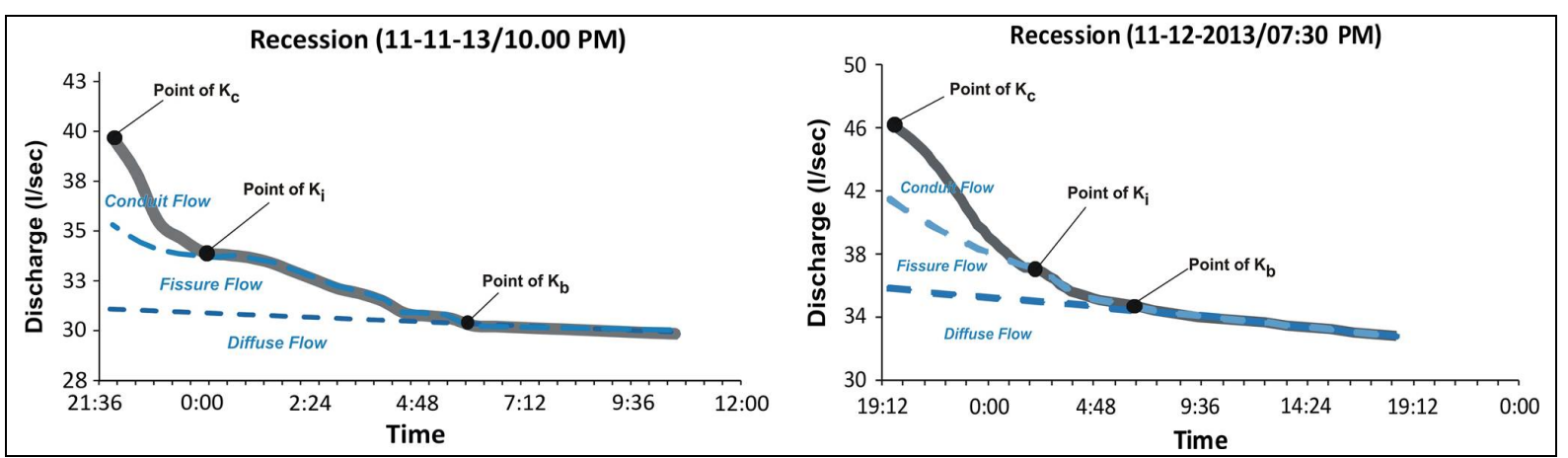

Gambar 5. Contoh pemisahan komponen aliran conduit, fissure, dan diffuse di Mataair Ngeleng/Petoyan, Gunungkidul, Provinsi DIY (Adji and Bahtiar, 2016)

Segmen resesi dapat dipilih dari suatu hidrograf banjir dan dapat dianalisis secara invividu atau bersama-sama untuk memperoleh pemahaman komponen-komponen aliran yang berpengaruh terhadap karakteristik aliran mantab (baseflow atau diffuse flow). Secara tradisional, analisis dilakukan dengan pendekatan grafikal tetapi pada saat ini lebih cenderung menggunakan model matematis (Adji dan Misqi, 2010). Masing-masing segmen resesi sering diangap sebagai penurunan secara eksponensial, seperti halnya yang ada pada fenomena fisika seperti aliran panas, difusi, atau radioaktif, yang diformulasikan sebagai berikut :

$$
Q_{t}=Q_{0} e^{-\alpha t}
$$

dimana $Q_{t}$ is adalah debit aliran pada waktu $t, Q_{0}$ adalah debit awal pada segmen resesi, dan $\alpha$ adalah suatu konstanta. Selanjutnya, $e^{-\alpha}$ pada rumus (1) dapat diganti dengan $k$, yang oleh hidrolog dikenal sebagai konstanta resesi (recession constant atau depletion factor), yang jamak digunakan sebagai indikator keberlangsungan aliran dasar (Nathan and McMahon, 1990; Worthington, 1991). Dari hasil penelitian, mereka membuat julat nilai konstanta resesi harian bervariasi dari 0,2-0,8 untuk channel flow; 0,7-0,94 untuk intermediate flow; dan 0,930,995 untuk baseflow. Semakin besar nilai kontanta resesi, maka semakin lambat pula akuifer karst melepaskan komponen alirannya ke mataair atau sungai bawah tanah.

Berikut ini contoh ringkasan sifat pelepasan aliran saat periode resesi (Tabel 3) yang terekam di beberapa lokasi di Sungai Bawah Tanah Bribin, Gunungkidul, Provinsi DIY dan sedikit deskripsi kondisi akuifernya atas dasar kriteria dari Nathan and McMahon (1990) dan Worthington (1991).

\section{Pemisahan aliran dasar}

Aliran dasar (baseflow) yang pada akuifer karst dikenal sebagai diffuse flow merupakan komponen aliran terpenting dari keseluruhan debit sungai bawah tanah atau mataair karst (Smathkin, 2001). Aliran diffuse ini berasal dari airtanah karst yang tersimpan di permukaan karst atau di retakan-retakan yang berukuran kecil, yang dilepaskan secara perlahan-lahan ke sungai bawah tanah atau mataair karst. Pada saat musim kemarau, debit mataair atau sungai bawah tanah hampir seluruhnya didominasi oleh aliran dasar, sedangkan saat musim hujan, debit aliran terdiri dari aliran dasar dan aliran cepat (quickflow). 
Adji, T.N., Cahyadi, A., 2016, Pentingnya Monitoring Parameter-Parameter Hidrograf Dalam Pengelolaan Airtanah di Daerah Karst, Seminar Nasional Ekohidrolika APCE-UNESCO, Jogjakarta, 12-14 Oktober 2016

Tabel 3. Kondisi pelepasan komponen aliran dan deskripsi simpanan airtanahnya atas dasar konstanta resesi, $\mathrm{T}_{\mathrm{p}}$ dan $\mathrm{T}_{\mathrm{b}}$ di SBT Bribin (Adji, 2010)

\begin{tabular}{|c|c|c|c|}
\hline $\begin{array}{l}\text { Paramater } \\
\text { hidrograf }\end{array}$ & $\begin{array}{l}\text { Sungai bawah } \\
\text { tanah }\end{array}$ & Perbandingan & Karakteristik \\
\hline$K_{b}=0,996$ & \multirow{5}{*}{ Gua Gilap } & $\begin{array}{l}>\text { Ngreneng } \\
<\text { Bribin }\end{array}$ & $\begin{array}{l}\text { - akuifer melepaskan aliran diffuse lebih cepat daripada GUA Bribin } \\
\text { tapi lebih lambat daripada GUA Ngreneng } \\
\text { - fungsi retakan kecil (diffuse) masih lebih baik dari GUA Ngreneng }\end{array}$ \\
\hline $\mathrm{K}_{\mathrm{i}}=0,767$ & & $\begin{array}{l}<\text { Ngreneng } \\
<\text { Bribin }\end{array}$ & $\begin{array}{l}\text { - simpanan air pada retakan berukuran menengah (fissure) paling } \\
\text { cepat dilepaskan dibanding di GUA Bribin dan Ngreneng }\end{array}$ \\
\hline $\mathrm{K}_{\mathrm{c}}=0,463$ & & $\begin{array}{l}>\text { Ngreneng } \\
>\text { Bribin }\end{array}$ & $\begin{array}{l}\text { - simpanan air pada retakan berukuran besar (conduit) paling lama } \\
\text { dilepas oleh akuifer } \\
\text { - luasan daerah tangkapannya paling kecil dibanding GUA Bribin } \\
\text { dan Ngreneng }\end{array}$ \\
\hline $\mathrm{T}_{\mathrm{p}}=3,03 \mathrm{jam}$ & & $\begin{array}{l}<\text { Ngreneng } \\
<\text { Bribin }\end{array}$ & - jarak tangkapan hujan paling dekat karena berada di bagian hulu \\
\hline $\mathrm{T}_{\mathrm{b}}=36,7 \mathrm{jam}$ & & $\begin{array}{l}>\text { Ngreneng } \\
>\text { Bribin }\end{array}$ & $\begin{array}{l}\text { - simpanan diffuse lama dilepas oleh akuifer } \\
\text { - retakan conduit belum berkembang sebaik GUA Bribin dan } \\
\text { Ngreneng }\end{array}$ \\
\hline$K_{b}=0,998$ & \multirow{5}{*}{ Gua Bribin } & $\begin{array}{l}>\text { Ngreneng } \\
>\text { Gilap }\end{array}$ & $\begin{array}{l}\text { - potensi simpanan diffuse paling baik karena paling lama dilepas } \\
\text { oleh akuifer } \\
\text { - debit masih besar di musim kemarau }\end{array}$ \\
\hline $\mathrm{K}_{\mathrm{i}}=0,825$ & & $\begin{array}{l}<\text { Ngreneng } \\
>\text { Gilap }\end{array}$ & $\begin{array}{l}\text { - simpanan pada retakan fissure relatif paling baik (hampir sama } \\
\text { dengan di Ngreneng }\end{array}$ \\
\hline $\mathrm{K}_{\mathrm{c}}=0,332$ & & $\begin{array}{l}<\text { Ngreneng } \\
<\text { Gilap }\end{array}$ & $\begin{array}{l}\text { - adanya point recharge saat hujan yang mengimbuh langsung ke } \\
\text { sungai, sehingga konstanta resesi saluran besar }\end{array}$ \\
\hline $\mathrm{T}_{\mathrm{p}}=5,5 \mathrm{jam}$ & & $\begin{array}{l}\text { > Ngreneng } \\
\text { > Gilap }\end{array}$ & - luas tangkapan hujan paling besar \\
\hline $\mathrm{T}_{\mathrm{b}}=36,3 \mathrm{jam}$ & & $\begin{array}{l}>\text { Ngreneng } \\
<\text { Gilap }\end{array}$ & $\begin{array}{l}\text { - komponen aliran conduit dan diffuse sama-sama dominan pada } \\
\text { saat banjir } \\
\text { - simpanan diffuse lama dilepas oleh akuifer }\end{array}$ \\
\hline$K_{b}=0,992$ & \multirow{5}{*}{$\begin{array}{l}\text { Gua } \\
\text { Ngreneng }\end{array}$} & $\begin{array}{l}<\text { Gilap } \\
<\text { Bribin }\end{array}$ & $\begin{array}{l}\text { - akuifer melepaskan komponen aliran diffuse paling cepat } \\
\text { dibanding GUA Gilap dan Bribin }\end{array}$ \\
\hline $\mathrm{K}_{\mathrm{i}}=0,877$ & & $\begin{array}{l}>\text { Gilap } \\
>\text { Bribin }\end{array}$ & - simpanan pada retakan fissure paling lama dilepas oleh akuifer \\
\hline $\mathrm{K}_{\mathrm{c}}=0,333$ & & $\begin{array}{l}<\text { Gilap } \\
>\text { Bribin }\end{array}$ & $\begin{array}{l}\text { - mulut gua merupakan point recharge aliran permukaan saat hujan } \\
\text { - merupakan bocoran dari S. Bribin sehingga nilainya hampir } \\
\text { identik }\end{array}$ \\
\hline $\mathrm{T}_{\mathrm{p}}=4,5 \mathrm{jam}$ & & $\begin{array}{l}>\text { Gilap } \\
<\text { Bribin }\end{array}$ & $\begin{array}{l}\text { - seharusnya nilainya identik dengan di Bribin, tetapi terpengaruh } \\
\text { aliran langsung ke mulut gua pada saat kejadian hujan }\end{array}$ \\
\hline $\mathrm{T}_{\mathrm{b}}=16,8 \mathrm{jam}$ & & $\begin{array}{l}<\text { Gilap } \\
<\text { Bribin }\end{array}$ & $\begin{array}{l}\text { - simpanan aliran dasar paling cepat dilepas oleh akuifer } \\
\text { - retakan conduit kemungkinan sudah dominan }\end{array}$ \\
\hline
\end{tabular}

${ }^{*} \mathrm{~K}_{\mathrm{c}}=$ konstanta resesi conduit; $\mathrm{K}_{\mathrm{i}}=$ konstanta resesi fissure; $\mathrm{K}_{\mathrm{b}}=$ konstanta resesi diffuse

$* \mathrm{~T}_{\mathrm{p}}=$ time to peak; $\mathrm{T}_{\mathrm{b}}=$ time to baseflow

Jika konstanta resesi aliran diffusse $\left(\mathrm{K}_{\mathrm{b}}\right)$ sudah terhitung, maka aliran dasar pada suatu sungai bawah tanah akan bisa dihitung baik dengan metode konvensional atau otomatik pada data time series yang panjang (misal 1 tahun). Pemisahan aliran dasar dari aliran total dapat dilakukan dengan beberapa metode di antaranya adalah metode grafis (Linsley et al, 1975), dengan metode empiris (Szilagyi and Parlange, 1998), atau dengan metode filter separation 
Adji, T.N., Cahyadi, A., 2016, Pentingnya Monitoring Parameter-Parameter Hidrograf Dalam Pengelolaan Airtanah di Daerah Karst, Seminar Nasional Ekohidrolika APCE-UNESCO, Jogjakarta, 12-14 Oktober 2016

Furey and Gupta (2001). Pada tulisan ini diberikan contoh pemisahan aliran dasar (diffuse flow separation) yang menggunakan metode otomatik, yaitu metode automated base flow separation by digital filtering (Eckhardt, 2005), yaitu mencari nilai digital filtering atas dasar nilai konstanta resesi aliran dasar $\left(\mathrm{K}_{\mathrm{b}}\right)$ pada kejadian hidrograf sepanjang tahun yang kemudian dihubungkan dengan nilai base flow indices maksimum $\left(\mathrm{BFI}_{\max }\right)$ di akuifer karst. Rumus yang dipakai adalah:

$$
q_{b(i)}=\frac{\left(1-B F I_{\max }\right) a q_{b(i-1)}+(1-a) B F I_{\max } q_{i}}{1-a B F I_{\max }}
$$

pada rumus di atas, $q_{b(i)}$ adalah baseflow pada saat $i, q_{b(i-1)}$ adalah baseflow pada waktu sebelumnya $i-1, q_{i}$ adalah total aliran pada waktu $i$, a adalah konstanta resesi dan $B F I_{\text {max }}$ adalah baseflow maksimum yang dapat diukur atau diketahui. Sementara itu, nilai $\mathrm{BFI}_{\max }$ yang dipergunakan di akuifer karst adalah 0,8 karena sifat akuifer karst yang porus dan sifat alirannya yang menahun (Eckhardt, 2005). Setelah dipisahkan, prosentase aliran dasar (PAD) bisa dihitung dengan membagi jumlah aliran dasar dengan total aliran (Adji et al, 2009)

Berikut ini contoh pemisahan aliran dasar (Gambar 6) dan perhitungan PAD (Tabel 4) di Gua Gilap (hulu SBT Bribin), Gunungkidul, DIY. Dengan mengetahui distribusi PAD maka akan dapat diperediksi berapa banyak debit andalan yang tersimpan di akuifer karst, khususnya untuk dilakkan pengelolaan pada musim sulit air (kemarau).

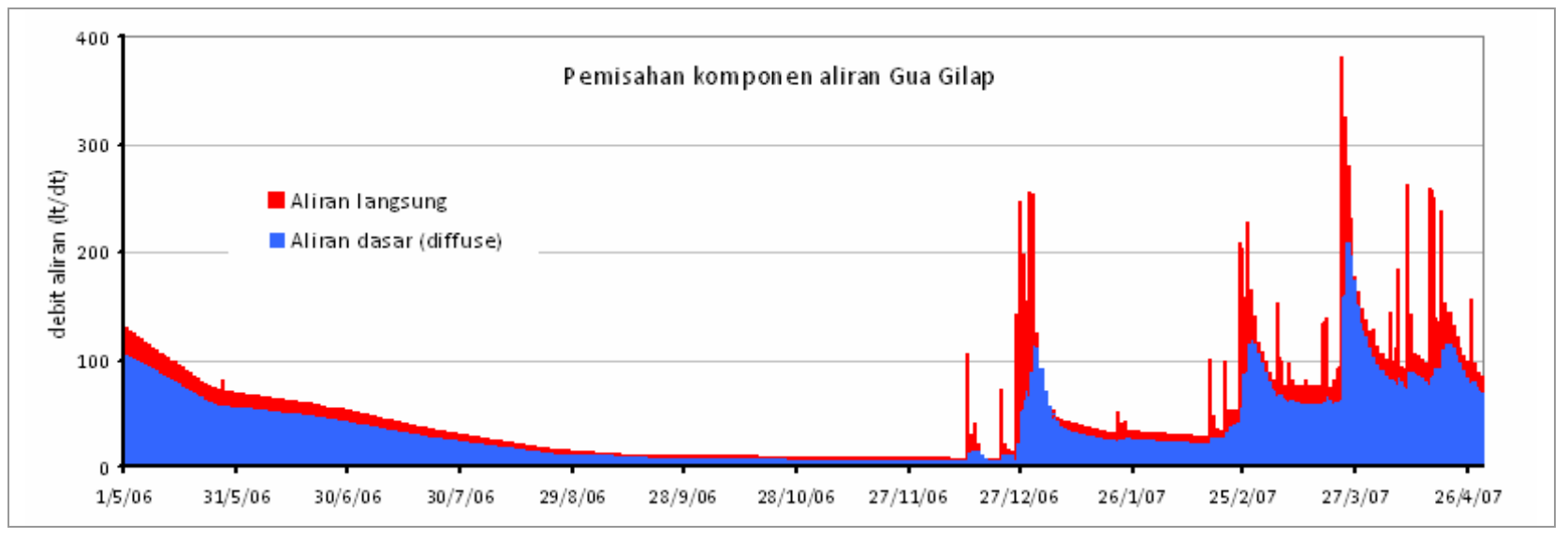

Gambar 6. Fluktuasi aliran dasar selama periode antara 1 Mei 2006 s.d. 31 Maret 2007 di Gua Gilap (Adji, 2011)

\section{Respon mataair atau SBT terhadap hujan}

Hubungan debit aliran dan hujan, secara tradisional sering digunakan di kalangan hidrologis untuk mengatahui sifat daerah tangkapan dalam menahan air dan melepaskannya ke mataair atau SBT (Brunsch et al, 2011). Lebih khusus, metode ini dapat dilakukan untuk memahami sistem perkembangan akuifer karst yaitu menggunakan hubungan antara input aliran berupa hujan dan output berupa debit mataair atau SBT karst. Secara metodologis, misalnya, Budge (2009), Fiorillo dan Doglioni (2010), serta Zhang et al. (2013) menggunakan metode korelasi silang untuk menganalisis hubungan linear antara curah hujan dan debit pada 
Adji, T.N., Cahyadi, A., 2016, Pentingnya Monitoring Parameter-Parameter Hidrograf Dalam Pengelolaan Airtanah di Daerah Karst, Seminar Nasional Ekohidrolika APCE-UNESCO, Jogjakarta, 12-14 Oktober 2016

mataair karst. Selanjutnya, tebal hujan dapat dikorelasikan terhadap besar fluktuasi debit mataair dan SBT. Korelasi secara temporal dapat memberikan gambaran mengenai respon akuifer yang berupa debit aliran airtanah terhadap curah hujan yang berperan sebagai imbuhan. Melalui pendekatan itulah dapat diketahui bagaimana sesungguhnya perilaku akuifer karst di suatu wilayah.

Tabel. 4. PAD pada kejadian banjir terpilih Gua Gilap

\begin{tabular}{|r|c|r|r|c|}
\hline \multicolumn{1}{|c|}{ No } & Waktu banjir & $\begin{array}{c}\text { Debit puncak } \\
\text { (It/dt) }\end{array}$ & $\begin{array}{c}\text { Prosentase Aliran Dasar } \\
\text { (PAD)- dalam \% }\end{array}$ & $\begin{array}{c}\text { Periode } \\
\text { hujan }\end{array}$ \\
\hline 1 & $13 / 12 / 06$ & 99,5 & 45,08 & Awal \\
\hline 2 & $22 / 12 / 06$ & 72,7 & 55,52 & Awal \\
\hline 3 & $31 / 12 / 06$ & 254,3 & 57,75 & Awal \\
\hline 4 & $16 / 2 / 07$ & 101,2 & 57,25 & Tengah \\
\hline 5 & $24 / 2 / 07$ & 208,0 & 51,25 & Tengah \\
\hline 6 & $26 / 2 / 07$ & 227,4 & 58,55 & Tengah \\
\hline 7 & $6 / 3 / 07$ & 153,4 & 79,91 & Akhir \\
\hline 8 & $9 / 3 / 07$ & 96,7 & 78,18 & Akhir \\
\hline 9 & $14 / 3 / 07$ & 81,1 & 78,92 & Akhir \\
\hline 10 & $19 / 3 / 07$ & 137,3 & 72,75 & Akhir \\
\hline 11 & $21 / 3 / 07$ & 100,5 & 77,20 & Akhir \\
\hline 12 & $23 / 3 / 07$ & 381,4 & 50,88 & Akhir \\
\hline 13 & $7 / 4 / 07$ & 182,6 & 70,33 & Akhir \\
\hline 14 & $10 / 4 / 07$ & 261,6 & 62,94 & Akhir \\
\hline 15 & $11 / 4 / 07$ & 142,7 & 76,30 & Akhir \\
\hline 16 & $16 / 4 / 07$ & 258,4 & 73,80 & Akhir \\
\hline
\end{tabular}

Sumber : hasil analisis data pada periode 2006-2007 (Adji, 2011)

Korelasi silang (Cross Correlation) merupakan salah satu metode yang banyak digunakan dalam analisis data secara time series hujan vs aliran. Metode ini dapat digunakan sebagai alat untuk memprediksikan suatu hubungan suatu series data $x$ (input) dengan data $y$ (output) pada suatu sistem. Untuk melakukan analisis korelasi silang, kedua data seri hujan dan aliran harus tersampel dalam interval waktu yang sama dan diasumsikan stasioner dalam mean dan varians (Cowpertwait dan Metcalfe, 2009, Shumway dan Stoffer, 2006, dalam Thomas, 2010). Hubungan kedua variabel tersebut didefinisikan dalam rumus:

$$
r_{x y}(k)=\frac{C x y(k)}{\sqrt{c_{x}^{2}(0) c_{y}^{2}(0)}}
$$

Di mana nilai $C_{z y}(\mathrm{k})$ merupakan cross correlogram. Puncak dari garfik cross correlogram (nilai $\mathrm{r}_{\mathrm{xy}}(\mathrm{k})$ tertinggi) merupakan estimasi time lag (waktu jeda) yang menunjukan cross correlation antara input dan output sistem.

$$
\begin{aligned}
& C_{\mathrm{xy}}(k)=\frac{1}{n} \sum_{t=1}^{n-k}\left(x_{\mathrm{t}}-\bar{x}\right)\left(y_{\mathrm{t}+\mathrm{k}}-\bar{y}\right) \\
& C_{\mathrm{x}}(0)=\frac{1}{n} \sum_{t=1}^{n}\left(x_{\mathrm{t}}-\bar{x}\right)^{2}
\end{aligned}
$$


Adji, T.N., Cahyadi, A., 2016, Pentingnya Monitoring Parameter-Parameter Hidrograf Dalam Pengelolaan Airtanah di Daerah Karst, Seminar Nasional Ekohidrolika APCE-UNESCO, Jogjakarta, 12-14 Oktober 2016

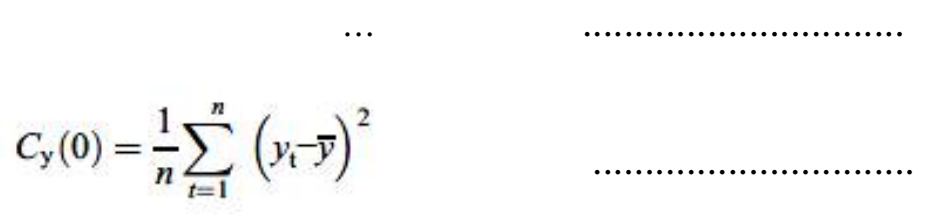

Sementara itu, $\mathrm{C}_{\mathrm{x}}(0)$ dan $\mathrm{C}_{\mathrm{y}}(0)$ merupakan rumus standar deviasi untuk masingmasing data series variabel $\mathrm{x}$ dan variabel y. Berikut ini contoh (Gambar 6) analisis hubungan hujan dan debit Mataair Ngeleng (Petoyan) di Gunungkidul, DIY.

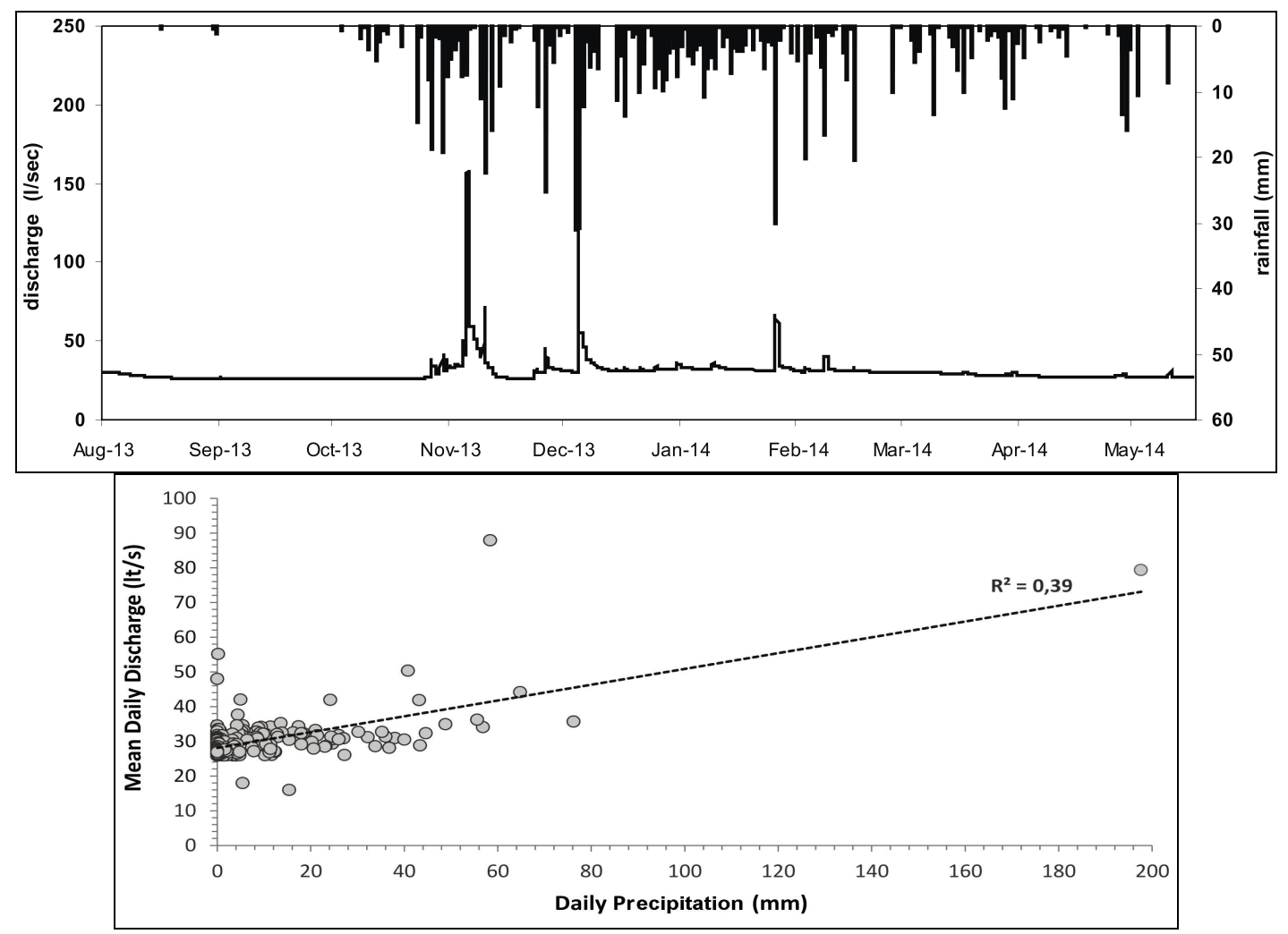

Gambar 6. Hubungan pasangan data hujan dan debit Mataair Ngeleng serta perhitungan korelasi-nya (Adji dan Bahtiar, 2016)

Dengan korelasi tersebut, akan diketahui bahwa antara curah hujan harian dan debit rata-rata Mataair Ngeleng memiliki nilai korelasi $\left(\mathrm{R}^{2}\right)$ sebesar 0,39, atau cukup signifikan. Atau dapat dipahami bahwa hubungan antara variabel independen (curah hujan) dan variabel dependen (debit mata air) berbanding lurus, atau dengan kata lain bahwa peningkatan curah hujan akan diikuti dengan peningkatan debit mata air. Jika diplot secara bivariate, hubungannya $(\mathrm{k})$ juga menunjukkan nilai positif, atau menunjukkan bahwa hubungan $\mathrm{k}$ (time lag) adalah positif, yang menunjukkan bahwa curah hujan mempengaruhi debit mataair (Zhang et al. 2013). Nilai korelasi nilai $\mathrm{r}_{\mathrm{xy}}(\mathrm{k})$ adalah yang tertinggi dalam jeda waktu sampai dua jam, dengan nilai korelasi 0,281. Selain itu, juga dapat diartikan bahwa akuifer Mataair Ngeleng akuifer merespon dalam bentuk peningkatan debit air pada interval dua jam sejak awal kejadian hujan. 
Adji, T.N., Cahyadi, A., 2016, Pentingnya Monitoring Parameter-Parameter Hidrograf Dalam Pengelolaan Airtanah di Daerah Karst, Seminar Nasional Ekohidrolika APCE-UNESCO, Jogjakarta, 12-14 Oktober 2016

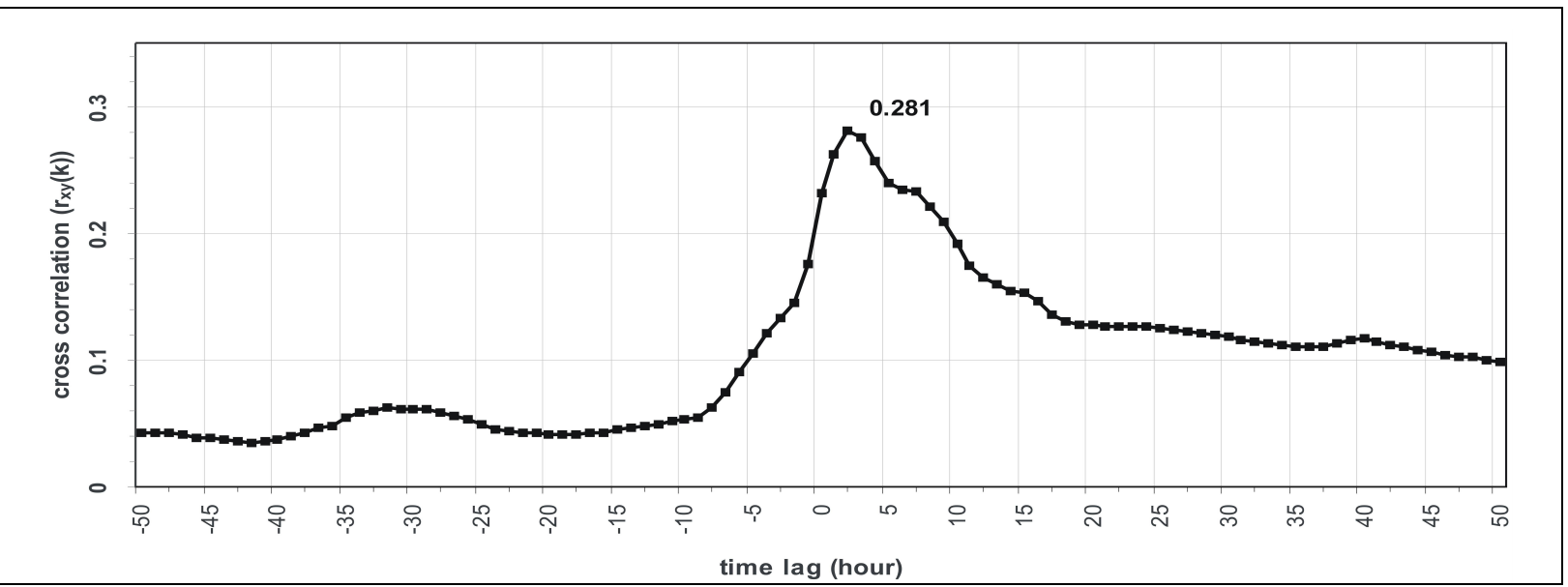

Gambar 7. Cross-Correlation Correlogram antara curah hujan and debit Mataair Ngeleng (Adji dan Bahtiar, 2016)

\section{Derajat (perkembangan) akuifer karst}

Khususnya di kawasan karst tropis, perkembangan karst lebih dipengaruhi oleh faktor curah hujan yang tinggi, temperatur yang hangat, lebatnya tutupan vegetasi yang menyebabkan tingginya konsentrasi $\mathrm{CO}_{2}$, serta besarnya potensi aliran airtanah (Nguyet, 2006). Tingkat perkembangan karstifikasi (karstification degree) ini sangat menentukan sifat akuifer dalam melepaskan simpanan airnya. Semakin tinggi derajat karstifikasi, maka saluran conduit akan semakin berkembang dengan konduktivitas hidraulik atau permeabilitas tinggi dengan sifat aliran cepat. Sementara itu, semakin rendah tingkat perkembangan karstifikasi, maka aliran akan didominasi oleh tipe diffuse dengan konduktivitas hidraulik yang rendah dan sifat aliran yang lambat (Baena et al., 2009). Oleh karena itu, derajat karstifikasi berperan secara mendasar untuk manajemen sumberdaya airtanah secara berkelanjutan.

Beberapa peneliti menggunakan parameter hidrograf untuk menghitung tingkat perkembangan karst, di antaranya adalah Rashed (2012). Metode Rashed (2012) ini menggunakan data-data yang diambil dari sebuah hidrograf banjir sejak mulai debit naik hingga debit kembali lagi menjadi aliran dasar (baseflow), termasuk data waktu dimulainya banjir, waktu puncak, dan waktu kembali menjadi baseflow. Komponen hidrograf ini diformulasikan dalam Rumus 7 dan diilustrasikan pada Gambar 8.

$$
D_{k}=\frac{\frac{Q_{\max }}{Q_{\min } t_{\text {event }}}}{t_{\text {peak }}}
$$

$\mathrm{t}_{\text {event }}$ dan $\mathrm{t}_{\text {peak }}$ didapat dari:

$$
\mathbf{t}_{\text {event }}=t_{C}-\mathbf{t}_{A}
$$


Adji, T.N., Cahyadi, A., 2016, Pentingnya Monitoring Parameter-Parameter Hidrograf Dalam Pengelolaan Airtanah di Daerah Karst, Seminar Nasional Ekohidrolika APCE-UNESCO, Jogjakarta, 12-14 Oktober 2016

$$
t_{\text {peak }}=t_{B}-t_{A}
$$

dimana $\mathrm{Q}_{\max }$ adalah debit maksimum di titik $\mathrm{B} ; \mathrm{Q}_{\min }$ merupakan debit minimum saat hidrograf mulai naik di titik $A ; t_{A}$ adalah waktu ketika mulai menaiknya hidrograf; $t_{B}$ adalah waktu ketika debit maksimum tercapai; dan $\mathrm{t}_{\mathrm{C}}$ merupakan waktu ketika hidrograf sudah kembali mencapai baseflow.

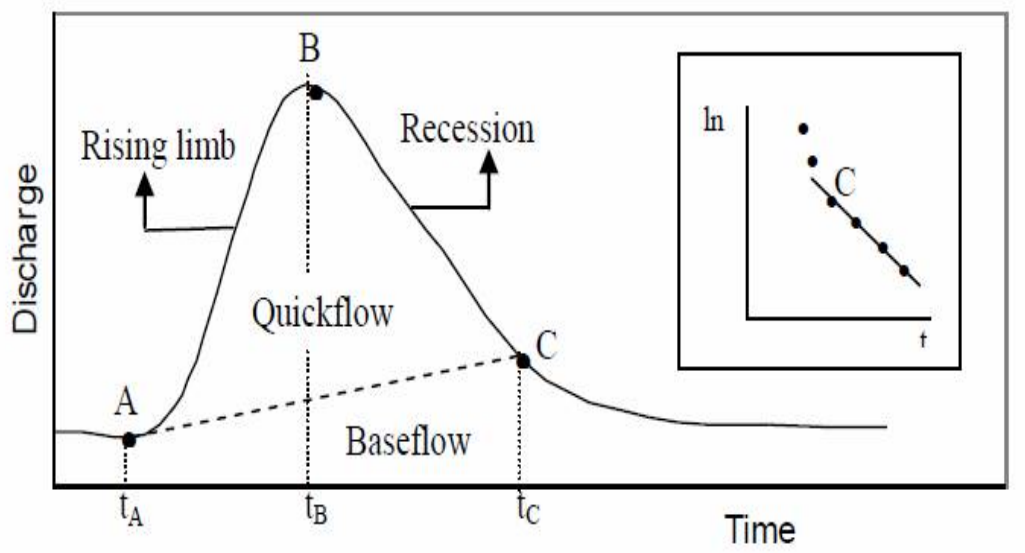

Gambar 8. Ilustrasi perhitungan derajat karstifikasi dengan rumus Rashed (2012)

Selanjutnya, nilai derajat karstifikasi $\left(\mathrm{D}_{\mathrm{k}}\right)$ diklasifikasikan menjadi 5 kategori akuifer berdasarkan Tabel 5.

Tabel 5. Klasifikasi tingkat perkembangan akuifer karst

\begin{tabular}{cl}
\hline $\mathbf{D}_{\mathbf{k}}$ & Klasifikasi \\
\hline$<\mathbf{1 0}$ & Akuifer yang sistemnya didominasi aliran diffuse (Darcian aquifer) \\
$\mathbf{1 0 - 2 0}$ & Akuifer yang telah terkarstifikasi sebagian (Partially karstified aquifer) \\
$\mathbf{2 0 - 6 0}$ & Akuifer yang telah terkarstifikasi (Karstified aquifer) \\
$>\mathbf{6 0}$ & Akuifer yang telah terkarstifikasi secara lanjut (Highly karstified aquifer) \\
\hline
\end{tabular}

Sumber : Rashed (2012)

Berikut ini contoh perhitungan derajat karstifikasi dengan rumus Rashed (2012) dan kondisi akuifernya (Tabel 6) di beberapa mataair dan SBT karst di Pulau Jawa (Adji, 2014)

Tabel 6. Kondisi airtanah di akuifer karst atas dasar derajat karstikasi dan parameter hidrograf lainnya di sebagian mataair dan SBT di Pulau Jawa

\begin{tabular}{|c|c|c|c|c|c|}
\hline $\begin{array}{l}\text { Mataair } \\
\text { \& SBT }\end{array}$ & $\begin{array}{c}\text { Derajat } \\
\text { karstifikasi }\end{array}$ & Bentuk Hidrograf & $\begin{array}{c}\text { Karakteristik } \\
\text { imbuhan }\end{array}$ & $\begin{array}{c}\text { Kapasitas } \\
\text { simpanan aquifer }\end{array}$ & PAD (\%) \\
\hline Beton & $\begin{array}{l}33,79 \\
\text { Karstified aquifer }\end{array}$ & $\begin{array}{l}\text { Rising limb meningkat } \\
\text { tajam, } \\
\text { recession limb saat awal } \\
\text { dan akhir musim } \\
\text { penghujan menurun secara } \\
\text { lambat, namun saat }\end{array}$ & \begin{tabular}{lr}
\multicolumn{2}{l}{ Dominan internal } \\
runoff dari ponor \\
dan \\
permukaan aliran \\
cekungan (doline).
\end{tabular} & $\begin{array}{l}\text { Kapasitas simpanan } \\
\text { pada awal dan akhir } \\
\text { musim hujan Tinggi, } \\
\text { namun saat } \\
\text { pertengahan musim } \\
\text { hujan rendah karena }\end{array}$ & $\begin{array}{l}\text { Rasio bulanan tinggi } \\
(80 \%), \\
\text { pemenuhan kapasitas } \\
\text { akuifer oleh aliran } \\
\text { dasar paling tinggi } \\
\text { pada pertengahan }\end{array}$ \\
\hline
\end{tabular}


Adji, T.N., Cahyadi, A., 2016, Pentingnya Monitoring Parameter-Parameter Hidrograf Dalam Pengelolaan Airtanah di Daerah Karst, Seminar Nasional Ekohidrolika APCE-UNESCO, Jogjakarta, 12-14 Oktober 2016

\begin{tabular}{|c|c|c|c|c|c|}
\hline $\begin{array}{l}\text { Mataair } \\
\text { \& SBT }\end{array}$ & $\begin{array}{c}\text { Derajat } \\
\text { karstifikasi }\end{array}$ & Bentuk Hidrograf & $\begin{array}{c}\text { Karakteristik } \\
\text { imbuhan }\end{array}$ & $\begin{array}{c}\text { Kapasitas } \\
\text { simpanan aquifer }\end{array}$ & PAD (\%) \\
\hline & & $\begin{array}{l}\text { pertengahan hujan } \\
\text { menurun secara cepat }\end{array}$ & & $\begin{array}{lr}\text { kapasitas } & \text { simpanan } \\
\text { penuh } & \text { dan } \\
\text { seluruhnya menjadi } \\
\text { aliran conduit }\end{array}$ & musim hujan (51.77\%) \\
\hline Petoyan & $\begin{array}{l}7,63 \\
\text { (Darcian aquifer) }\end{array}$ & $\begin{array}{l}\text { Rising limb meningkat } \\
\text { tajam, } \\
\text { recession limb menurun } \\
\text { secara lambat }\end{array}$ & $\begin{array}{l}\text { Dominan diffuse } \\
\text { infiltration, diikuti } \\
\text { dengan shaft flow } \\
\text { dari rekahan dan } \\
\text { ponor }\end{array}$ & $\begin{array}{l}\text { Kapasitas simpanan } \\
\text { akuifer paling rendah } \\
\text { diantara yang lain. } \\
\text { daerah imbuhan } \\
\text { tidak terlalu luas. }\end{array}$ & $\begin{array}{l}\text { Rasio bulanan tinggi. } \\
\text { Persentase aliran dasar } \\
\text { paling tinggi saat awal } \\
\text { dan akhir musim } \\
\text { penghujan. }\end{array}$ \\
\hline Gilap & $\begin{array}{l}25,13 \\
\text { (Karstified } \\
\text { aquifer) }\end{array}$ & $\begin{array}{l}\text { Rising limb meningkat } \\
\text { cepat, recession limb } \\
\text { menurun secara bertahap } \\
\text { dan lambat }\end{array}$ & $\begin{array}{l}\text { Dominan internal } \\
\text { runoff melalui } \\
\text { ponor dan rekahan } \\
\text { fissures }\end{array}$ & $\begin{array}{l}\text { Kapasitas simpanan } \\
\text { tinggi, lebih bagus } \\
\text { daripada Ngreneng }\end{array}$ & $\begin{array}{l}\text { Rasio bulanan tinggi } \\
(80 \%) \text {, akhir musim } \\
\text { penghujan paling tinggi } \\
(72 \%)\end{array}$ \\
\hline Ngreneng & $\begin{array}{l}4,08 \\
\text { (Partially } \\
\text { Karstified aquifer) }\end{array}$ & $\begin{array}{l}\text { Rising limb meningkat } \\
\text { tajam, recession limb } \\
\text { menurun secara cepat. }\end{array}$ & $\begin{array}{l}\text { Dominan internal } \\
\text { runoff dari doline } \\
\text { sekitarnya }\end{array}$ & $\begin{array}{l}\text { Kapasitas simpanan } \\
\text { sedang, lebih rendah } \\
\text { dari Gilap }\end{array}$ & $\begin{array}{l}\text { Rasio bulanan tinggi } \\
(80 \%), \% \text { baseflow } \\
\text { paling tinggi } r \text { saat } \\
\text { pertengahan } \text { musim } \\
\text { hujan }(48 \%)\end{array}$ \\
\hline Seropan & $\begin{array}{l}\text { 3,03 } \\
\text { (Darcian aquifer) }\end{array}$ & $\begin{array}{l}\text { Rising limb saat awal dan } \\
\text { pertengahan musim hujan } \\
\text { meningkat dengan sangat } \\
\text { lambat, namun rising limb } \\
\text { di akhir musim penghujan } \\
\text { meningkat tajam. } \\
\text { Recession limb menurun } \\
\text { dengan sangat lambat. }\end{array}$ & $\begin{array}{l}\text { Dominan Diffuse } \\
\text { Infiltration }\end{array}$ & $\begin{array}{lr}\text { Kapasitas } & \text { simpanan } \\
\text { sangat tinggi, namun } \\
\text { saat akhir } r \text { musim } \\
\text { penghujan } & \text { rendah } \\
\text { karena } & \text { kapasitas } \\
\text { simpanan } & \text { sudah } \\
\text { penuh } & \end{array}$ & $\begin{array}{l}\text { Rasio bulanan tinggi } \\
(80 \%), \% \text { baseflow } \\
\text { paling tinggi saat } \\
\text { pertengahan musim } \\
\text { penghujan }(70.4 \%)\end{array}$ \\
\hline Toto & $\begin{array}{l}4,09 \\
\text { (Darcian aquifer) }\end{array}$ & $\begin{array}{l}\text { Rising limb meningkat } \\
\text { secara perlahan, } \\
\text { Recession limb menurun } \\
\text { dengan sangat lambat }\end{array}$ & $\begin{array}{l}\text { Dominan Diffuse } \\
\text { Infiltration }\end{array}$ & $\begin{array}{l}\text { Kapasitas simpanan } \\
\text { akuifer sangat tinggi }\end{array}$ & $\begin{array}{l}\text { Rasio bulanan tinggi } \\
(80 \%), \% \text { baseflow } \\
\text { paling tinggi dicapai } \\
\text { saat awal dan akhir } \\
\text { musim penghujan }\end{array}$ \\
\hline Bribin & $\begin{array}{l}6,82 \\
\text { (Darcian aquifer) }\end{array}$ & $\begin{array}{l}\text { Rising limb meningkat } \\
\text { cepat, recession limb } \\
\text { menurun secara bertahap } \\
\text { dan lambat, sama dengan } \\
\text { Gilap }\end{array}$ & $\begin{array}{l}\text { Dominan internal } \\
\text { runoff dan pasokan } \\
\text { dari sistem SBT } \\
\text { Bribin hulu dan } \\
\text { tengah }\end{array}$ & $\begin{array}{l}\text { Kapasitas simpanan } \\
\text { akuifer sangat tinggi }\end{array}$ & $\begin{array}{l}\text { Rasio bulanan sangat } \\
\text { tinggi }(97-99 \%), \% \\
\text { baseflow pada akhir } \\
\text { musim penghujan } \\
\text { paling tinggi hingga } \\
\text { mencapai } 97 \%\end{array}$ \\
\hline Ngerong & $\begin{array}{l}9,27 \\
\text { (Darcian aquifer) }\end{array}$ & $\begin{array}{l}\text { Rising limb meningkat } \\
\text { cepat, namun lebih lambat } \\
\text { dari Bribin, Gilap, dan } \\
\text { Ngreneng. Recession limb } \\
\text { menurun secara bertahap } \\
\text { (< Ngreneng) }\end{array}$ & \begin{tabular}{lr}
\multicolumn{2}{l}{ Dominan internal } \\
runoff dari ponor \\
dan & aliran \\
permukaan di & dingan (doline).
\end{tabular} & $\begin{array}{l}\text { Kapasitas simpanan } \\
\text { tinggi }\end{array}$ & $\begin{array}{l}\text { Rasio bulanan tinggi. \% } \\
\text { baseflow paling tinggi } \\
\text { terjadi pada } \\
\text { pertengahan musim } \\
\text { hujan }(57 \%)\end{array}$ \\
\hline
\end{tabular}

Sumber: (Adji, 2014)

Metode lain untuk menentukan nilai karstification degree $\left(\mathrm{D}_{\mathrm{k}}\right)$ sebuah akuifer karst adalah dengan cara memvalidasi sub regime aliran (laminer atau turbulen) yang terekam pada sebuah kurva resesi banjir pada mataair karst. Perbedaan utama metode ini dengan metodemetode sebelumnya adalah dalam satu kurva resesi bisa memiliki satu atau lebih sub regim aliran Malik danVotjkova (2012).

Pada metode ini aliran laminer (diffuse) dan turbulent (conduit) dibedakan dengan perhitungan Reynolds number, yang diketahui bahwa aliran laminer memiliki nilai $\mathrm{N}_{\mathrm{Re}}<2000$, sedangkan aliran turbulent memiliki nilai $\mathrm{N}_{\mathrm{Re}} \geq 2000$ dan nilai maksimum aliran turbulent adalah $\mathrm{N}_{\mathrm{Re}}=10000$ (Ford and William, 2007). Sub-rezim koefisien aliran laminer dihitung menggunakan Rumus Maillet (1905), sedangkan sifat aliran turbulen $t$ dihitung dari Rumus Kullman (1983) dan Malik danVotjkova (2012) yang diformulasikan pada:

$Q_{t}=Q_{0}(1-\beta t)$ 
Adji, T.N., Cahyadi, A., 2016, Pentingnya Monitoring Parameter-Parameter Hidrograf Dalam Pengelolaan Airtanah di Daerah Karst, Seminar Nasional Ekohidrolika APCE-UNESCO, Jogjakarta, 12-14 Oktober 2016

koefisien $\beta$ pada Rumus 5 dihitung dari Rumus Drogue, 1972 dalam Fiorillo (2014), diformulasikan dalam:

$\beta=\alpha\left(Q_{0}{ }^{-\frac{1}{n}}\right)$

Koefisien $\alpha$ dan $\beta$ kemudian digunakan untuk menentukan nilai parameter kurva resesi. Berdasarkan nilai linear dan koefisien resesi sub regim aliran, Malik (2007) membuat suatu index yang disebut tingkat karstifikasi. Tingkat karstifikasi berdasarkan rumus kurva resesi dibagi menjadi 10 kelas. Kelas 1 untuk tingkat karstifikasi yang paling rendah, yakni resesi debit hanya berisi komponen aliran laminar, sedangkan tingkat karstifikasi paling tinggi adalah kelas 10 untuk tingkat karstifikasi yang paling tinggi, yaitu resesi debit hanya berisi komponen aliran turbulent. Contoh pemisahan dan penentuan koefisien $\alpha$ dan $\beta$ dalam satu kurva resesi ditunjukkan pada Gambar 9.

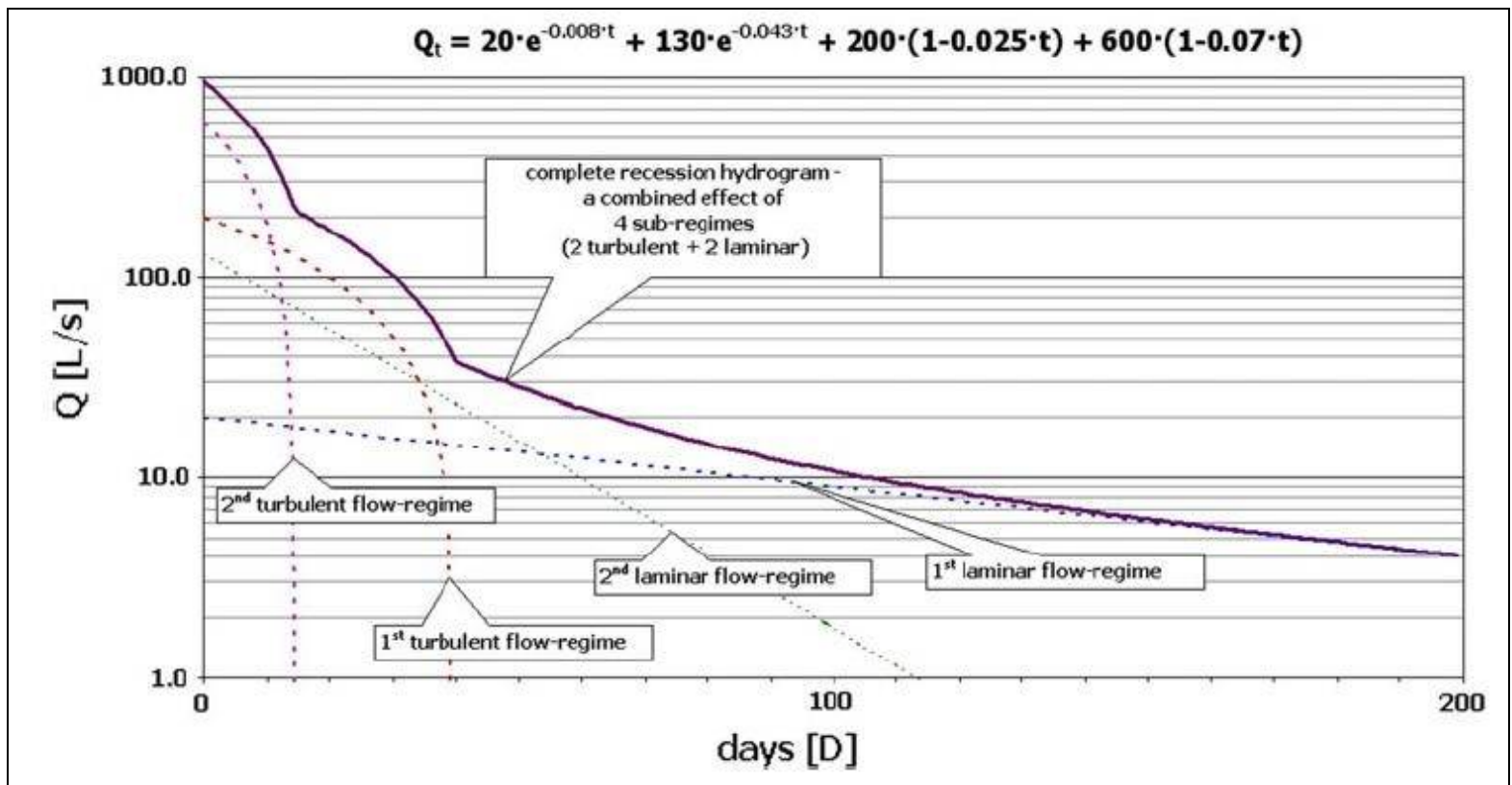

Gambar 9. Contoh kurva resesi dengan 2 aliran laminer dan 2 aliran turbulen (Malik and Votjkova, 2012)

Selanjutnya, pembagian tingkat kartifikasi dan ringkasan rumus kurva resesi terangkum pada Tabel 7.

Tabel 7. Tingkat karstifikasi akuifer karst berdasarkan parameter kurva resesi

\begin{tabular}{|c|c|l|}
\hline $\begin{array}{c}\text { Tingkat } \\
\text { Karstifikasi }\end{array}$ & \multicolumn{1}{|c|}{ Rumus Kurva Resesi } & \multicolumn{1}{c|}{$\begin{array}{c}\text { Parameter Koefisien } \\
\text { resesi }\end{array}$} \\
\hline $0.5-2.3$ & $\mathrm{Q}_{\mathrm{t}}=\mathrm{Q}_{01} \mathrm{e}^{-\mathrm{alt}}$ & $\mathrm{\alpha}_{1}<0.001$ \\
& & $\begin{array}{l}\mathrm{\alpha}_{1}=0.001-0.0025 \\
\mathrm{\alpha}_{1}=0.0025-0.007 \\
\mathrm{\alpha}_{1}>0.007\end{array}$ \\
\hline
\end{tabular}


Adji, T.N., Cahyadi, A., 2016, Pentingnya Monitoring Parameter-Parameter Hidrograf Dalam Pengelolaan Airtanah di Daerah Karst, Seminar Nasional Ekohidrolika APCE-UNESCO, Jogjakarta, 12-14 Oktober 2016

\begin{tabular}{|c|c|c|}
\hline $\begin{array}{c}\text { Tingkat } \\
\text { Karstifikasi }\end{array}$ & Rumus Kurva Resesi & $\begin{array}{l}\text { Parameter Koefisien } \\
\text { resesi }\end{array}$ \\
\hline $2.5-4.0$ & $Q_{t}=Q_{01} e^{-\alpha 1 t}+Q_{02} e^{-\alpha 2 t}$ & $\begin{array}{l}\alpha_{1}<0.0024 \text { dan } \alpha_{2}<0.033 \\
\alpha_{1}>0.0043 ; \text { dan } \alpha_{2}<0.060\end{array}$ \\
\hline $4.3-5.0$ & $Q_{t}=Q_{01} e^{-a 1 t}+Q_{04}\left(1-\beta_{1} t\right)$ & $\begin{array}{l}\alpha_{1}>0.018 \text { atau } \alpha_{2}>0.16 \\
\alpha_{1}>0.018 \text { dan } \alpha_{2}>0.16 \\
\text { Nilai } \beta \text { dan } \alpha \text { rendah }\end{array}$ \\
\hline 5.5 & $Q_{t}=Q_{01} e^{-a 1 t}+Q_{02} e^{-a 2 t}+Q_{04}\left(1-\beta_{1} t\right)$ & $\alpha_{1}>0$ dan $\alpha_{2}>0 ; \beta_{1}>0$ \\
\hline 6.0 & $Q_{t}=Q_{01} e^{-\alpha 1 t}+Q_{02} e^{-\alpha 2 t}+Q_{04}\left(1-\beta_{1} t\right)+Q_{05}\left(1-\beta_{2} t\right)$ & Nilai $\beta_{2}, \beta_{1}$ dan $\alpha_{1}, \alpha_{2}$ tinggi \\
\hline 7.0 & $Q_{t}=Q_{01} e^{-\alpha 1 t}+Q_{04}\left(1-\beta_{1} t\right)+Q_{05}\left(1-\beta_{2} t\right)+Q_{06}\left(1-\beta_{3} t\right)$ & $\begin{array}{l}\text { Nilai } \beta_{3}, \beta_{2}, \beta_{1} \text { dan } \alpha \text { tinggi, } \\
\beta_{1}>\beta_{2}\end{array}$ \\
\hline 8.5 & $\mathrm{Q}_{\mathrm{t}}=\mathrm{Q}_{04}\left(1-\beta_{1} \mathrm{t}\right)$ & $\alpha_{1}, \alpha_{2}=0$ dan $\beta_{1}>0$ \\
\hline 9 & $Q_{\mathrm{t}}=Q_{04}\left(1-\beta_{1} \mathrm{t}\right)+\mathrm{Q}_{05}\left(1-\beta_{2} \mathrm{t}\right)$ & Nilai $\beta_{1}$ dan $\beta_{2}$ rendah \\
\hline 10.0 & $Q_{t}=Q_{04}\left(1-\beta_{1} t\right)+Q_{05}\left(1-\beta_{2} t\right)+Q_{06}\left(1-\beta_{3} t\right)$ & Nilai $\beta_{1}, \beta_{2}$, dan $\beta_{3}$ tinggi \\
\hline
\end{tabular}

Sumber : Malik and Votjkova (2012)

Berikut ini contoh perhitungan derajat karstifikasi dengan rumus Malik and Votjkova, (2012) serta sifat perkembangan akuifernya (Tabel 7) di beberapa mataair dan SBT karst di Pulau Jawa (Adji, 2015).

Tabel 7. Sebaran spasial derajat karstikasi di sebagian mataair dan SBT di Pulau Jawa

\begin{tabular}{|c|c|c|c|}
\hline $\begin{array}{c}\text { Mataair dan } \\
\text { SBT }\end{array}$ & $\begin{array}{c}\text { Derajat } \\
\text { karstifikasi }\end{array}$ & Rumus kurva resesi & Deskripsi \\
\hline Mataair Beton & 6,6 & $\begin{array}{l}\text { Qt }=2.384-0.009 t+ \\
3.304(1-005 t)+7.216(1- \\
0.0005 t)\end{array}$ & $\begin{array}{l}\text { Akuifer karst yang telah terkarstifikasi pada tingkat dewasa } \\
\text { karena pengaruh patahan dan saluran karst terbuka, dengan } \\
\text { saluran conduit dan non-karst yang telah berkembang dan } \\
\text { menuju pada perkembangan muka airtanah freatik secara } \\
\text { wilayah }\end{array}$ \\
\hline Mataair Petoyan & 3,7 & $\begin{array}{l}\text { Qt }=+0.0340 .0703 t \\
0.0350 .0159 t+ \\
0.0680 .0555 t\end{array}$ & $\begin{array}{l}\text { Akuifer kast dengan perkembangan jaringan fissure yang belum } \\
\text { seragam, mayoritasnya adalah makrofissure terbuka dan minim } \\
\text { adanya saluran karst (conduit). Saat periode banjir ada } \\
\text { kemungkinan (langka) terjadi aliran turbulen dalam jangka } \\
\text { pendek }\end{array}$ \\
\hline SBT Gilap & 5,8 & $\begin{array}{l}\text { Qt }=0.103^{-0.0256 t}+ \\
0.183(1-0.145 t)\end{array}$ & $\begin{array}{l}\text { Mulai adanya karstifikasi dan pelarutan batuan karbonat, dengan } \\
\text { pelorongan yang terbentuk mulai bersifat terbuka, berukuran } \\
\text { sedang (fissure), baik dialami oleh batuan yang mudah atau sulit } \\
\text { larut di zone freatik. Sifat aliran sedikit dipengaruhi oleh saluran } \\
\text { terbuka (conduit) yang saling berhubungan }\end{array}$ \\
\hline SBT Ngreneng & 6,0 & $\begin{array}{l}\text { Qt }=0.191^{0.0019 t} \\
0.260(1-0.851 t)+ \\
0.385(1-0.099 t)\end{array}$ & $\begin{array}{l}\text { Mulai adanya karstifikasi dan pelarutan batuan karbonat, dengan } \\
\text { pelorongan yang terbentuk mulai bersifat terbuka, berukuran } \\
\text { sedang (fissure), baik dialami oleh batuan yang mudah atau sulit } \\
\text { larut di zone freatik. Sifat aliran sedikit dipengaruhi oleh saluran } \\
\text { terbuka (conduit) yang saling berhubungan }\end{array}$ \\
\hline SBT Seropan & 5,2 & $\begin{array}{l}\text { Qt }=0.218^{0.0045 t}+ \\
0.244^{0.0186 t}+0.424(1- \\
0.0365 t)\end{array}$ & $\begin{array}{l}\text { Akuifer dengan adanya masukan air dari zona sesar di daerah } \\
\text { hulu (missal), dengan perkembangan jaringan saluran kecil } \\
\text { (diffuse-fissure) yang cukup intensif, sebagiannya bersifat } \\
\text { terbuka dan sudah mempunyai sistem air freatik yang bersifat }\end{array}$ \\
\hline
\end{tabular}


Adji, T.N., Cahyadi, A., 2016, Pentingnya Monitoring Parameter-Parameter Hidrograf Dalam Pengelolaan Airtanah di Daerah Karst, Seminar Nasional Ekohidrolika APCE-UNESCO, Jogjakarta, 12-14 Oktober 2016

\begin{tabular}{|l|l|l|l|}
\hline SBT Toto & & & terbuka \\
\hline SBT Bribin & 5,0 & $\begin{array}{l}\text { Qt }=1.447^{-0.009 t}+ \\
1.639(1-0.000019 t)\end{array}$ & $\begin{array}{l}\text { Akuifer dengan adanya masukan air dari zona sesar di daerah } \\
\text { hulu (misal), dengan perkembangan jaringan saluran kecil } \\
\text { (diffuse-fissure) yang cukup intensif, sebagiannya bersifat } \\
\text { terbuka dan sudah mempunyai sistem air freatik yang bersifat } \\
\text { terbuka }\end{array}$ \\
\hline SBT Ngerong & 7,7 & $\begin{array}{l}\text { Qt }=1.847^{-0.0007 t}+ \\
1.911(1-0007)+ \\
1.936(1-0.0028 \mathrm{t})\end{array}$ & $\begin{array}{l}\text { Akuifer terkarstifikasi pada tingkat yang sangat berkembang, } \\
\text { yang didominasi oleh saluran terbuka (conduit) yang besar. } \\
\text { Peran dari saluran mengengah (fissure) dan jaringan saluran } \\
\text { kecil (diffuse network) sudah sangat minim. Zona freatik sudah } \\
\text { hilang atau perannya sudah tidak lagi signifikan. Hampir seluruh } \\
\text { siklus airtanah telah bergabung pada sistem saluran terbuka. }\end{array}$ \\
\hline 4,8 & $\begin{array}{l}\text { Qt }=1.447^{-0.009 t} \\
1.639(1-0.000019 t)\end{array}$ & $\begin{array}{l}\text { Akuifer dengan adanya masukan air dari zona sesar di daerah } \\
\text { hulu (misal), dengan perkembangan jaringan saluran kecil } \\
\text { (diffuse-fissure) yang cukup intensif, sebagiannya bersifat } \\
\text { terbuka dan sudah mempunyai sistem air freatik yang bersifat } \\
\text { terbuka }\end{array}$ \\
\hline
\end{tabular}

Sumber : Adji (2015)

\section{Hidrokemograf}

Hidrokemograf adalah grafik yang menggambarkan hubungan antara debit dan kimia airtanah secara time-series. Analisis time series pada waktu yang panjang dan hidrokemograf saat kejadian banjir dapat dipakai untuk mencari hubungan antar faktor-faktor yang berpengaruh pada suatu akifer karst, sebagai contoh pada parameter $\mathrm{pH}$, suhu, hujan, $\mathrm{P}_{\mathrm{CO} 2}$, kalsium, dan bikarbonat. Shuster dan White (1971) adalah yang pertama kali menggunakan metode ini untuk mengklasifikasikan akuifer karst, baik itu akuifer diffuse (darcian) ataupun akuifer conduit pada sebuah mataair karst. Pada akuifer yang bersifat diffuse, debitnya biasanya kecil dan dikontrol oleh struktur dan stratigrafi asli dari batuan akuifer. Akuifer diffuse ini juga tidak terlalu menunjukkan variasi musiman atau pun setelah kejadian hujan puncak karena debit mataair didominasi oleh cadangan air yang sudah ada di akuifer, sehingga dijumpai hanya sedikit variasi kimianya dari waktu ke waktu. Sebaliknya, pada akuifer yang bertipe conduit, maka daya hantar listrik, debit, dan kandungan ion dalam air sangat bervariasi, bersifat musiman, atau berubah-ubah sesuai kejadian hujan (Adji, 2005).

Lebih jauh lagi model hidrokemograf yang paling masyhur adalah yang dipublikasikan oleh Plagnes dan Balakowicz (2001), yang menyimpulkan adanya tiga model kemograf pada mataair dan sungai bawah tanah karst, yaitu: (i) komposisi kimia air sepanjang waktu hampir sama pada saat hidrograf mulai naik. Komposisi terlarut kemudian naik sedikit, dan TDS kembali kepada kondisi saat sebelum banjir; (ii) air dengan komposisi mineral lebih banyak muncul pada saat kenaikan hidrograf, kemudian turun sampai di bawah komposisi sebelum banjir, dan pada resesi kemudian kembali ke posisi awal; (iii) bervariasi secara teratur sesuai variasi hidrograf alirannya.

Berikut ini disajikan contoh analisis hidrokemograf di SBT Bribin saat kejadian banjir dan analisis bivariate plot-nya untuk mengetahui proses yang bertanggung jawab terhadap perkembangan lorong di daerah tangkapan SBT Bribin (Gambar 10). Dalam analisis hidrokemograf-nya, Adji (2012) menyimpulkan bahwa saat musim hujan, hidrokimia di SBT Bribin sangat dipengaruhi oleh prosentase aliran dasar (diffuse) dalam air. Meskipun, saat kejadian banjir, air SBT didominasi oleh aliran dari lorong conduit yang menyebabkan penurunan nilai kalsium dan bikarbonat. Pada keadaan ini, korelasi antara aliran dasar vs $\mathrm{Ca}^{2+}$ 
Adji, T.N., Cahyadi, A., 2016, Pentingnya Monitoring Parameter-Parameter Hidrograf Dalam Pengelolaan Airtanah di Daerah Karst, Seminar Nasional Ekohidrolika APCE-UNESCO, Jogjakarta, 12-14 Oktober 2016

dan $\mathrm{HCO}_{3}{ }^{-}$akan rendah. Sebaliknya, saat periode resesi setelah kejadian banjir, dominasi conduit digantikan oleh aliran diffuse, yang mendorong proses water-rock-interaction. Tahap ini ditandai dengan meningkatnya $\mathrm{Ca}^{2+}$ dan $\mathrm{HCO}_{3}{ }^{-}$dalam air, dan penurunan kadar $\mathrm{CO}_{2}$, dan hidrokimia yang hampir mirip dengan yang ditemukan pada musim kemarau. Dari hidrokemograf di SBT Bribin dapat diketahui bahwa bahwa ukuran lorong kecil-menengah di akuifer SBT Bribin akuifer masih dominan untuk menyimpan aliran dasar, meskipun lorong yang berukuran conduit juga sudah berkembang yang ditunjukkan dengan dominasinya saat acara banjir.

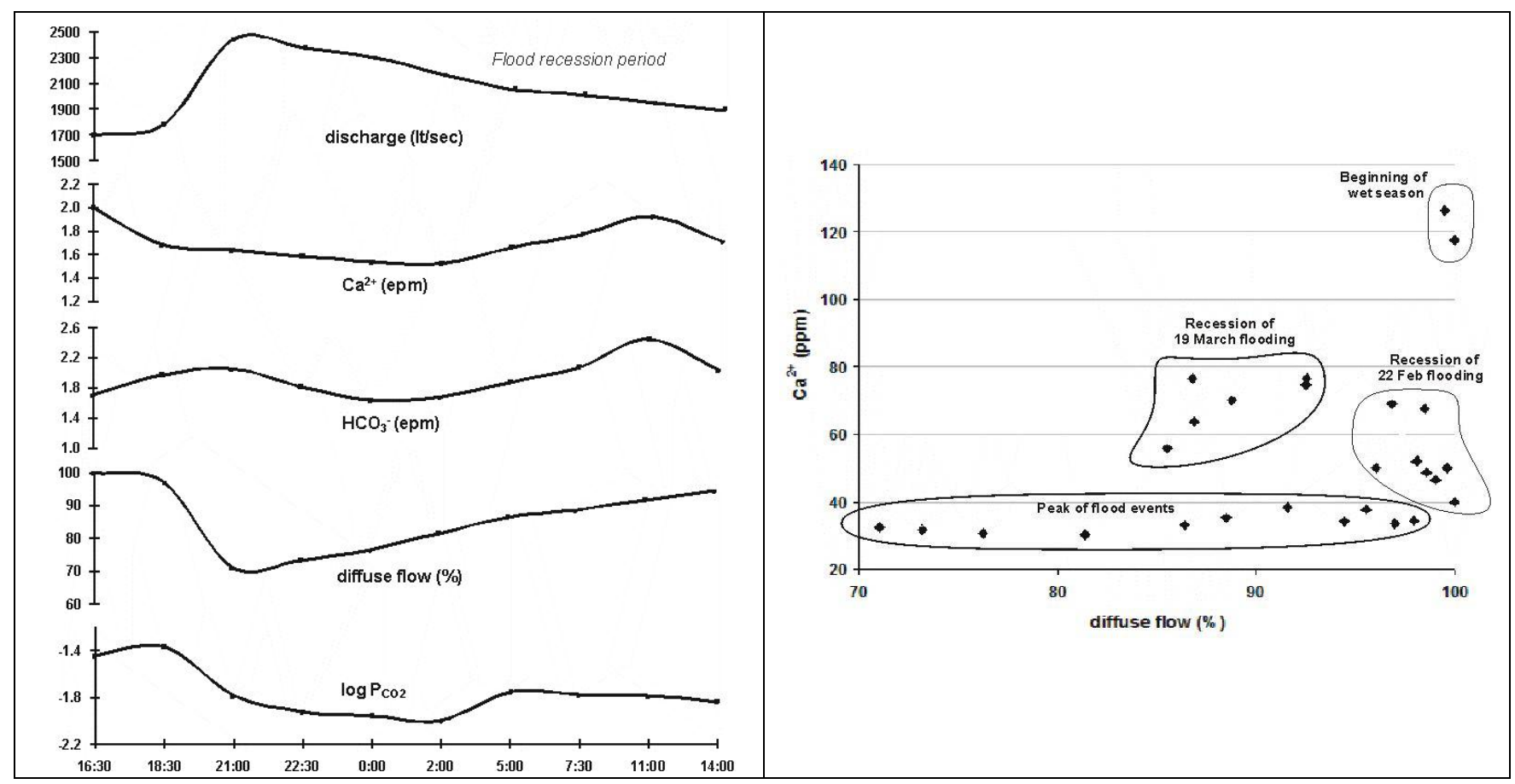

Gambar 10. Hidrokemograf saat kejadian banjir (kiri) dan hubungan kalsium vs aliran dasar di SBT Bribin (Adji, 2012)

\section{PENUTUP}

Untuk mengelola sumberdaya air karst, tentunya diperlukan pengetahuan yang rinci terkait dengan sifat-sifat akuifernya, berapa besar simpanannya, bagaimana karakteristik imbuhannya, bagaimana fluktuasi aliran dasarnya sepanjang tahun, bagaimana sifat alirannya saat mengimbuh mataair atau SBT, reaksi kimia apa yang dominan, dll, yang semuanya tadi terkait dengan tingkat perkembangan pelorongan karst pada suatu kawasan. Terlebih lagi pada masa ini, pengetahuan yang rinci tentang sifat akuifer karst baik secara spasial maupun temporal sungguh sangat dituntut. Hal ini mengingat bahwa kawasan karst dianggap merupakan salah satu kawasan yang potensial secara tambang dan mineralogis, sehingga kadang kala muncul konflik antara pihak-pihak yang berkepentingan untuk mengonservasi atau memanfaatkannya. 
Adji, T.N., Cahyadi, A., 2016, Pentingnya Monitoring Parameter-Parameter Hidrograf Dalam Pengelolaan Airtanah di Daerah Karst, Seminar Nasional Ekohidrolika APCE-UNESCO, Jogjakarta, 12-14 Oktober 2016

Secara histori hidrologis, pendekatan dengan menganalisis hidrograf aliran dan parameternya dipandang oleh para ahli merupakan cara yang paling tepat mengingat hidrograf merupakan cerminan dari kondisi dan proses yang terjadi di akuifer yang dialirkan ke mataair atau SBT yang kemudian dipasang alat pencatat variasi dan perubahan hidrograf alirannya. Dengan kata lain, hidrograf aliran merupakan visualisasi atau gambaran dari rekaman proses yang terjadi di akuifer karst yang dikontrol oleh proses pelarutan batuan gamping. Adapun ringkasan sifat akuifer dan aliran yang bisa dirinci dari analisis pada sebuah hidrograf aliran karst disajikan pada Tabel 8.

Tabel 8. Parameter hidrograf aliran dan sifat akuifer karst yang berkaitan dengannya

\begin{tabular}{|c|c|c|}
\hline No & $\begin{array}{c}\text { Parameter } \\
\text { Hidrograf Aliran }\end{array}$ & Sifat akuifer karst \\
\hline 1 & $\begin{array}{l}\text { Hidrograf banjir }\left(Q_{\max }\right. \\
\left.T_{p}, T_{b}\right)\end{array}$ & $\begin{array}{l}\text { Besar kecilnya daerah tangkapan } \\
\text { Hubungan aliran mataair atau SBT } \\
\text { Besar kecilnya simpanan air di akuifer karst } \\
\text { Sifat imbuhan dari akuifer ke SBT atau mataair } \\
\text { Kerentanan akuifer terhadap pencemar dari permukaan }\end{array}$ \\
\hline 2 & $\begin{array}{l}\text { Hidrograf resesi - } \\
\text { konstanta resesi }\left(\mathrm{K}_{\mathrm{b}} \text {, }\right. \\
\left.\mathrm{K}_{\mathrm{i}}, \mathrm{K}_{\mathrm{c}}\right)\end{array}$ & $\begin{array}{l}\text { Sifat akuifer dalam melepaskan aliran diffuse, fissure, conduit } \\
\text { Perkembangan dan dominasi lorong kecil, sedang, besar } \\
\text { Besar kecilnya simpanan air di akuifer karst } \\
\text { Besar kecilnya debit andalan secara time-series } \\
\text { Prediksi debit andalan pada waktu ke-t } \\
\text { Kerentanan akuifer terhadap pencemar dari permukaan }\end{array}$ \\
\hline 3 & $\begin{array}{l}\text { Pemisahan aliran } \\
\text { dasar }\end{array}$ & $\begin{array}{l}\text { Prosentase aliran dasar } \\
\text { Fluktuasi aliran dasar dan aliran cepat secara time series }\end{array}$ \\
\hline 4 & Hubungan hujan-debit & $\begin{array}{l}\text { Cepat lambatnya respon mataair atau SBT terhadap hujan } \\
\text { Sifat daerah tangkapan dalam menahan air sebelam dilepas } \\
\text { Perkembangan dan dominasi jenis lorong di akuifer } \\
\text { Kerentanan akuifer terhadap pencemar dari permukaan }\end{array}$ \\
\hline 5 & $\begin{array}{l}\text { Konstanta resesi ó dan } \\
\beta\end{array}$ & $\begin{array}{l}\text { Derajat karstifikasi/perkembangan akuifer karst } \\
\text { Dominasi jenis aliran di akuifer karst } \\
\text { Lorong yang dominan di akuifer karst } \\
\text { Kerentanan akuifer terhadap pencemar dari permukaan }\end{array}$ \\
\hline 6 & Hidrokemograf & $\begin{array}{l}\text { Kualitas air karst } \\
\text { Hubungan antara kandungan kimia dominan dengan debit atau aliran dasar } \\
\text { Agresivitas air karst untuk melarutkan batuan gamping } \\
\text { Proses-proses kimia yang bertanggung jawab terhadap pelebaran lorong di } \\
\text { akuifer karst } \\
\text { Kerentanan akuifer terhadap pencemar dari permukaan }\end{array}$ \\
\hline
\end{tabular}

\section{Daftar Pustaka}

Adji, T. N., 2010. Spatial and Temporal Variation of Hydrogeochemistry and Karst Flow Properties to Characterize Karst Dynamic System in Bribin Underground River, Gunung Kidul Regency, DIY Province Java, Indonesia. Dissertation in Geography Study Program. Graduate School of Geography, Gadjah Mada University, Yogyakarta

Adji, T.N. 2012, Wet Season Hydrochemistry of Bribin River in Gunung Sewu Karst, Indonesia, Environmental Earth Sciences, Vol. 67:1563-1572 pp 
Adji, T.N., Cahyadi, A., 2016, Pentingnya Monitoring Parameter-Parameter Hidrograf Dalam Pengelolaan Airtanah di Daerah Karst, Seminar Nasional Ekohidrolika APCE-UNESCO, Jogjakarta, 12-14 Oktober 2016

Adji, T.N. and Haryono, E., 1999. Konflik Antara Pemanfaatan Batugamping dan Konservasi Sumberdaya Air Das Bribin di Wilayah Karst Gunung Sewu, Makalah Lokakarya Nasional Menuju Pengelolaan Sumberdaya Wilayah Berbasis Ekosistem Untuk Mereduksi Konflik Antar Daerah, Yogjakarta, , Fakultas Geografi, Universitas Gadjah Mada, September 1999

Adji, T.N., 2005, Agresivitas Airtanah Karst Sungai Bawah Tanah Bribin, Gunung Sewu, Indonesian Cave and Karst Journal, Vol. 1 No1, HIKESPI

Adji, T.N., 2010. Variasi Spasial-Temporal Hidrogeokimia dan Sifat Aliran Untuk Karakterisasi Sistem Karst Dinamis di Sungai Bawah Tanah Bribin, Kabupaten Gunung Kidul, DIY, Disertasi, Fakultas Geografi, Universitas Gadjah Mada, Yogyakarta

Adji, T.N., 2011, Pemisahan aliran dasar (diffuse flow) hulu daerah tangkapan hujan Sungai Bribin pada aliran Gua Gilap, Karst Gunung Sewu, Gunung Kidul, Yogyakarta, Jurnal Geologi Indonesia ,Vol 6, No.3, Sept. 2011

Adji, T.N., 2011, Upper catchment of Bribin underground river hydrogeochemistry (Gunung Sewu Karst, Gunung Kidul, Java, Indonesia) Proceeding of Asian Trans-Disclipinary Karst Conference, Yogyakarta

Adji, T.N., 2011. Pemisahan aliran dasar bagian hulu Sungai Bribin pada aliran Gua Gilap, di Karst Gunung Sewu, Gunung Kidul, Yogyakarta, Jurnal Geologi Indonesia, Vol. 6 No. 3 September 2011

Adji, T.N., 2013, Hubungan Karakter Aliran dan Sifat Kimia Mataair Petoyan Untuk Karakterisasi Akuifer Karst, Hibah Dana Masyarakat Fak. Geografi UGM

Adji, T.N., 2013. Hydrogeochemistry and Karst Flow Properties of Bribin River, Indonesia Paperback - June 5, 2013, LAP LAMBERT Academic Publishing ISBN-10: 3659373214 Saarbrücken, Germany

Adji, T.N., 2014, Analisis Hidrograf Aliran Untuk Penentuan Derajat Karstifikasi Pada Beberapa Kondisi Mataair dan Sungai Bawah Tanah Karst, Hibah Dana Masyarakat Fak. Geografi UGM

Adji, T.N., 2015, Sebaran Spasial Tingkat Karstifikasi Area Pada Beberapa Mataair dan Sungai Bawah Tanah Karst Menggunakan Rumus Resesi Hidrograph Malik and Vojtkova (2012), Hibah BOPTN Fak. Geografi UGM

Adji, T.N., 2016, Distribusi Spasial Respon Debit Mataair dan Sungai Bawah Tanah Terhadap Hujan Untuk Prediksi Kapasitas Penyimpanan Air oleh Akuifer Karst di Sebagian Wilayah Karst di Pulau Jawa, Hibah BOPTN Fak. Geografi UGM

Adji, T.N., 2016. Bagaimana memprediksi kerusakan sumberdaya air karst, Makalah pada seminar internal "Konsolidasi Pengelolaan Ekosistem Karst dan pembahasan RPP Pengelolaan Ekosistem Karst", Kementrian Lingkungan Hidup dan Kehutanan, 6 Juni 2016, link download:https://www.academia.edu/25907154/BAGAIMANA_MEMPREDIKSI_KERUSA KAN_SUMBERDAYA_AIR_KERUSAKAN_SUMBERDAYA_AIR_KARST

Adji, T.N., Bahtiar, I.Y., 2016. Rainfall-discharge relationship and karst flow components analysis for karst aquifer characterization in Petoyan Spring, Java, Indonesia, Environmental Earth Sciences, 75:735

Adji, T.N., Haryono, E., Fatchurrohman, H., Oktama, R., 2015. Diffuse flow characteristics and their relation to hydrochemistry conditions in the Petoyan Spring, Gunungsewu Karst, Java, Indonesia, Geosciences Journal, Vol. 20, No. 3, p. 381-390, June 2016

Adji, T.N., Haryono, E., Woro, S, 1999, Kawasan Karst dan Prospek Pengembangannya di Indonesia, Seminar PIT IGI di Universitas Indonesia, 26-27 Oktober 1999 
Adji, T.N., Cahyadi, A., 2016, Pentingnya Monitoring Parameter-Parameter Hidrograf Dalam Pengelolaan Airtanah di Daerah Karst, Seminar Nasional Ekohidrolika APCE-UNESCO, Jogjakarta, 12-14 Oktober 2016

Adji, T.N., Hendrayana, H., Sudarmadji, E., Woro, S, 2009, Diffuse Flow Separation Within Karst Underground River at Ngreneng Cave, Proceeding of International Conference Earth Science and Technology, 6-7 Aug 2009, Yogyakarta

Adji, T.N., Misqi, M., 2010, The Distribution of Flood Hydrograph Recession Constant for Characterization of Karst Spring and Underground River Flow Components Releasing Within Gunung Sewu Karst Region, Indonesian Journal of Geography, XLII(1)

Adji, T.N., Mujib, M.A., Fatchurohman, H., Bahtiar, I.Y., 2014, Analisis Tingkat Perkembangan Akuifer Karst di Kawasan Karst Gunung Sewu, Daerah Istimewa Yogyakarta dan Karst Rengel, Tuban, Jawa Timur Berdasarkan Analisis Hidrograf, Prosiding PIT IGI ke-17, UNY, Jogjakarta, 15 Nov 2014

Brunsch A, Adji, TN, Stoffel D, Ikhwan M, Oberle P, Nestmann F (2011) Hydrological assessment of a karst area in Southern Java with respect to climate phenomena, Proceeding of Asian Trans-Disciplinary Karst Conference, Yogyakarta

Baena, CL. B. Andreo, J. Mudry, F. Carrasco cantos. 2009. Groundwater temperature and electrical conductivity as tools to characterize flow patterns in carbonate aquifers: The Sierra de las Nieves karst aquifer, Southern Spain. Hydrogeology Journal, 17:843-853.

Bonacci, O., 1993. Karst springs hydrographs as indicators of karst aquifers. Hydrological Sciences 38 (1) : 51-62.

Brosig, K., Geyer, T., Subah, A., Sauter, M., 2008. Travel time based approach for the assessment of vulnerability of karst groundwater: the Transit Time Method, Environmental Geology, 54:905911

Budge, T. J., 2009, Modeling the Usefulness of Spatial Correlation Analysis on Karst Systems. Groundwater, 47, 427-437.

Dane, F.C. 1990. Research Methods, Brooks/Cole Publishing Company, Pacific Grove, California

Doerfliger, N. and Zwahlen, F., 1998. Practical Guide, Groundwater Vulnerability Mapping in Karstic region (EPIK). Swiss Agency for the Environment, Forests and landscape (SAEFL), Bern, 56 pp.

Domenico, P.A. and Schwartz, F.W., 1990. Physical and Chemical Hydrogeology. $2^{\text {nd }}$ Ed. John Wiley \& Sons

Dreiss, S.J., 1989. Regional scale transport in a karst aquifers: linear systems and time moment analysis. Water Resources Research. 25 (1) pp 126-134.

Fiorillo, F. and Doglioni, A., 2010, The Relation Between Karst Spring Discharge and Rainfall by Cross-Correlation Analysis. Hydrogeology Journal, 18, 1881-1895.

Fiorillo, F., 2014. The recession of spring Hydrograph, focused on karst aquifer. Journal of Water Management : Volume 28, Issue 7, pp 1781-1805

Ford, D., Williams, P. 2007. Karst Hydrogeology and Geomorphology. John Wiley \& Sons, Ltd.

Furey, P.R., Gupta, V.K., 2001. A physically based filter for separating base flow from streamflow time series. Water Resources Research 37(11):2709-2722.

Gillieson, D., 1996. Caves: Processes, Development, and Management, Blackwell, Oxford

Goldscheider, N., 2002. Hydrogeology and vulnerability of karst systems - examples from the Northern Alps and Swabian Alb.- PhD Thesis. University of Karlsruhe, Faculty for Bio- and Geoscience, 236 p., Karlsruhe.

Haryono, E., Adji, T.N., 2004. Geomorfologi dan Hidrologi Karst, Bahan Ajar, Kelompok Studi Karst, Fakultas Geografi Universitas Gadjah Mada, Yogyakarta http://tjahyoadji.staff.ugm.ac.id/buku_ajar_karst_indonesia.pdf 
Adji, T.N., Cahyadi, A., 2016, Pentingnya Monitoring Parameter-Parameter Hidrograf Dalam Pengelolaan Airtanah di Daerah Karst, Seminar Nasional Ekohidrolika APCE-UNESCO, Jogjakarta, 12-14 Oktober 2016

Kresic, N. and Bonacci, O., 2010. Spring Discharge Hydrograph. In Kresic, N. and Zoran Stevanovic. 2010. Groundwater Hydrology of Springs: engineering, theory, management, and sustainability. Butterworth-Heinemann.

Kullman, E., 1983, Rez`im podzemny'ch vo^d s turbulentny'm pru'deni'm v puklinovo-krasovom horninovom prostred1'. [Groundwater regime with turbulent flow in fissure-karst rock environment (in Slovak)]. Geologicky' u'stav Diony'za S ` tu'ra, Bratislava, Geologicke' pra'ce 79:237-262

Lastennet, R. and Mudry, J., 1997. Role of karstification and rainfall in the behavior of heterogeneous karst system. Enviromental Geology 32 (2) September 1997: Springer-Verlag, pp 114-123.

Leibundgut, C., 1998. Karst Hydrology (Proceedings of Workshop W2), Rabat, Morocco, IAHS Publication no. 247

Linsley, R.K., Kohler, M.A., Paulhus, J.L.H., Wallace, J.S., 1975. Hydrology for engineers. McGraw Hill, New York

Maillet, E., 1905, Essais d'Hydraulique Souteeraine et Fluviale. Hermann, Paris

Malik, P., 2007, Assessment of regional kastification degree and groundwater sensitivity to pollution using hydrograph analysis in the Velka Fatra Mountains, Slovakia. Environmental Geology (51):707-711.

Malik, P.,Vojtkova, S., 2012. Use of recession-curve analysis for estimation of karstification degree and its application in assessing overflow/underflow conditions in closely spaced karstic springs, Environmental Earth Sciences, Springer, April 2012, Volume 65, Issue 8, pp 22452257.

Mangin, A., 1975. Contribution a` l'e'tude hydrodynamique des aquife'res karstiques (Contributions to the hydrodynamics of karst aquifers). The 'se, Universite' de Dijon, p 124

Margat, J., 1968, Vulne'rabilite' des nappes d'eau souterraine a` la pollution (Aquifer vulnerability). BRGM-Publication 68, SGL 198, HYD, Orleans

Mohammadi, Z. and Shoja, A., 2013. Effect of annual rainfall amount on characteristics of karst spring hydrograph. Carbonate and Evaporites. Volume 29,(3), pp 279-289

Nathan R.J., McMahon T.A., 1990. Evaluation of automated techniques for baseflow and recession analysis. Water Resources Research. 26(7):1465-1473

Plagnes, V., Bakalowicz, M., 2001. May it propose a unique interpretation for karstic spring chemographs? In: J. Mudry and F. Zwahlen (Editors), 7th Conference on Limestone Hydrology and Fissured Media. Franche-Comté University, Besançon, pp. 293-298.

Quinlan, J.F., 1989. Ground-water monitoring in karst terraces: recommended protocols and implicit assumptions. US Environmental Protection Agency Environmental Monitoring Systems Laboratory, Las Vegas.

Quinlan, J.F., Smart, P.L., Schindel, G.M., Alexander, E.C., Edwards, A.J., Smith, A.R., 1991. Recommended administrative/regulatory definitions of karst aquifer. Principles for classification of carbonate aquifers. Practical evaluation of vulnerability of karst aquifers and determination of optimum sampling frequency at springs. In: Quinlan JF, Stanley A (eds), Hydrology, ecology, monitoring and management of ground water in karst terraces conference, 3rd, Proceedings: Dublin, Ohio, National Ground Water Association, pp 573-635.

Raeisi, E. and Karami, G. 1997. Hydrochemographs of berghan karst spring as Indicators of aquifer characteristics. Journal of Cave and Karst Studies 59(3): 112-118.

Rashed, K. A., 2012. Assessing degree of karstification: a new method of classifying karst aquifers. Sixteenth International Water Technology Conference, IWTC 16 2012, Istanbul, Turkey

Schulz, E.F., 1976. Problems in Applied Hydrology. Water Resources Publication, Colorado 
Adji, T.N., Cahyadi, A., 2016, Pentingnya Monitoring Parameter-Parameter Hidrograf Dalam Pengelolaan Airtanah di Daerah Karst, Seminar Nasional Ekohidrolika APCE-UNESCO, Jogjakarta, 12-14 Oktober 2016

Shuster, E. T., White, W. B., 1971. Seasonal fluctuations in the chemistry of limestone Springs: a possible means for characterizing Carbonate aquifers. Journal of Hydrology 14: 93-128

Smakhtin, V.U., 2001. Estimating continuous monthly baseflow time series and their possible applications in the context of the ecological reserve, Water SA Vol. 27 No. 2, pp 213-218

Smart, P.L., Hobbs, S.L., 1986. Characteristics of Carbonate Aquifers: A conceptual basis. In Proceedings, Environmental Problem in Karst Terrains and Their Solution. Bowling Green, KY: National Well Water Association, 1-4

Szilagyi, J., Parlange, M.B., 1998. Baseflow separation based on analytical solutions of the Boussinesq equation. Journal of Hydrology 204:251-260

Thomas, B.C., 2010. Comparison of Two Physically-Based Spatially Distributed Hydrology Models in Contrasting Geo-Climatic Settings. Master Thesis. Faculty of Geo-information Science and Earth, ITC, The Netherlands

Trudgil, S., 1985. Limestone Geomorphology, Longman, New York.

White, W. B., Elizabeth L. W. 2003. Conduit fragmentation, Cave patterns, and the localization of karst groundwater basins: The Appalachians as test case. Speleogenesis and evolution of karst aquifer I (2) : 1-15

White, W.B., 1988. Geomorphology and Hydrology of Karst Terrain. Oxford University Press, New York

White, W.B., 1993. Analysis of Karst Aquifer. In:Alley, W.M. (editor), Regional Groundwater Quality. Van Nostrand Reinhold, New York

Williams, P.W., 1983. The role of the subcutaneous zone in karst hydrology. In: Back W and LaMoreaux PE (Guest-Editors) V.T. Spingfield symposium-processes in karst hydrology. J Hydrol 61:45-67

Zhang, Z., Chen, Xi, Chen X., Shi, P., 2013, Quantifying Time Lag of Epikarst-Spring Hydrograph Response to Rainfall Using Correlation and Spectral Analyses. Hydrogeology Journal, 21, 1619631 .

Zhu, X., Zhu, D., Zhang, Y., Lynch, E.M., 2013. Tower karst and cone karst. In: Shroder, J. (Editor in Cheif), Frumkin A (Ed) Treatise on Geomorphology, Academic Press, San Diego, CA, vol. 6, Karst Geomorphology, pp 327-340. 